\title{
The Effect of Lime, Irrigation-water Source, and Water-soluble Fertilizer on Root-zone pH, Electrical Conductivity, and Macronutrient Management of Container Root Media with Impatiens
}

\author{
William R. Argo ${ }^{1}$ and John A. Biernbaum ${ }^{2}$ \\ Department of Horticulture, Michigan State University, East Lansing, MI 48824-1325 \\ Additional index words. calcium, magnesium, peat, phosphorus, tissue analysis, soilless root media, subirrigation, soluble \\ salts, sulfate
}

\begin{abstract}
Hybrid impatiens (Impatiens Wallerana Hook. F.) were planted in a peat-based medium containing two dolomitic liming materials $\left(1.8 \mathrm{~kg} \mathrm{Ca}(\mathrm{OH})_{2} \bullet \mathrm{Mg}(\mathrm{OH})_{2} / \mathrm{m}^{3}\right.$ or $\left.8.4 \mathrm{~kg} \mathrm{CaCO} \cdot \mathrm{MgCO}_{3} / \mathrm{m}^{3}\right)$ and subirrigated for 17 weeks using four irrigation-water sources (IWSs) with varied bicarbonate alkalinity, $\mathrm{Ca}^{2+}, \mathrm{Mg}^{2+}$, and $\mathrm{SO}_{4}-\mathrm{S}$ content and three water-soluble fertilizers (WSFs) that contained (in mg) $200 \mathrm{~N}-20 \mathrm{P}-200 \mathrm{~K} /$ liter but a variable $\mathrm{NH}_{4}: \mathrm{NO}_{3}$ ratio, $\mathrm{Ca}^{2+}, \mathrm{Mg}^{2+}$, and SO$_{4}-\mathrm{S}$ content. The factorial arrangement of the IWS and WSF resulted in a range of $\mathrm{Ca}^{2+}, \mathrm{Mg}^{2+}$, and $\mathrm{SO}_{4}-\mathrm{S}_{\text {concentrations }}$ varying by a factor of 10 . After 8 weeks, medium $\mathrm{pH}$ ranged from 4.5 to 8.5 . The maximum critical medium $\mathrm{pH}^{-}$for $\mathrm{PO}_{4}-$ $P$ uptake was 7.4 to 7.7 , which probably was due to a change in most of the water-soluble $P$ to the less-available $\mathrm{HPO}_{4}{ }^{2-}$ form. Lime type did not affect the long-term increase in medium $\mathrm{pH}, \mathrm{Ca}^{2+}$, and $\mathrm{Mg}^{2+}$ concentrations with nutrient solutions containing low $\mathrm{NH}_{4}{ }_{-}^{-} \mathrm{N}$ and high $\mathrm{Ca}^{2+}$ and $\mathrm{Mg}^{2+}$. The carbonate lime buffered the medium $\mathrm{pH}$ and $\mathrm{Ca}^{2+}$ and $\mathrm{Mg}^{2+}$ concentrations with nutrient solutions containing high $\mathrm{NH}_{4}^{+}-\mathrm{N}$ and low $\mathrm{Ca}^{2+}$ and $\mathrm{Mg}^{2+}$ compared to that measured with the hydrated lime. With both lime types, there was a linear increase in tissue $\mathrm{Ca}$ and $\mathrm{Mg}$ as the applied concentrations of the various nutrient solutions increased from 18 to $210 \mathrm{mg} \mathrm{Ca}^{2+} /$ liter and 7 to $90 \mathrm{mg} \mathrm{Mg} \mathrm{g}^{2+} /$ iter. The relationship was similar for both lime types up to week 8 , after which tissue $\mathrm{Ca}$ and $\mathrm{Mg}$ decreased more rapidly with the hydrated lime and low solution $\mathrm{Ca}^{2+}$ and $\mathrm{Mg}^{2+}$ compared to that of the same carbonate lime treatments. The minimum critical $\mathrm{SO}_{4}-\mathrm{S}$ concentration in the applied nutrient solution for plant uptake was 30 to $40 \mathrm{mg} \mathrm{S} / \mathrm{liter}$. Below this concentration, tissue $S$ decreased rapidly; above, there was little effect on tissue $S$.
\end{abstract}

A number of factors, which include lime, the irrigation-water source (IWS), water-soluble fertilizer (WSF), and plant growth, interact to affect the management of $\mathrm{pH}$ and nutrient concentrations in container root media throughout crop production. However, not all factors affect medium $\mathrm{pH}$ and macronutrient management simultaneously. A better understanding of how these factors interact is necessary to improve the recommendations for $\mathrm{pH}$ and nutrient management of container-grown crops over a wide range of conditions.

Lime is added to a soilless root medium to neutralize acidity and increase the $\mathrm{pH}$ to an acceptable level for plant growth. Incorporating sufficient lime into a soilless root medium to obtain an initial $\mathrm{pH}$ range of 5.5 to 6.4 is recommended (Nelson, 1991; Peterson, 1981; Warncke and Krauskopf, 1983). The amount of liming material required to obtain an equilibrium $\mathrm{pH}$ of 6 in the root medium depends on the incorporation rate and particle size (Argo and Biernbaum, 1996; Chapin, 1980; Gibaly and Axley, 1955; Schollenberger and Salter, 1943; Sheldrake, 1980; Williams et al.,

Received for publication 3 July 1995. Accepted for publication 27 Nov. 1995. We acknowledge the Michigan Agricultural Experiment Station, Bedding Plant Foundation, Horticulture Research Institute, Fafard, Western Michigan Bedding Plant Association, and Gloeckner Foundation for supporting this research. Plant materia was provided by Wooden Shoe Greenhouses, Holland, Mich., and plant tissue analysis was provided by the Fafard Analytical Services, Athens, Ga. We also acknowledge the help and advice of R. Heins and M. Yelanich with the nonlinear regression analysis. The use of trade names in this publication does not imply endorsement of the products named or criticism of similar ones not mentioned. The cost of publishing this paper was defrayed in part by the payment of page charges. Under postal regulations, this paper therefore must be hereby marked advertisement solely to indicate this fact.

${ }^{1}$ Graduate research assistant.

${ }^{2}$ Associate professor. 1988b) as well as the surface area of the liming material (Parfitt and Ellis, 1966). There is some information about the time required for the lime to reach a stable $\mathrm{pH}$ in soilless medium (Argo and Biernbaum, 1996; Williams et al., 1988b), the effect of water alkalinity in conjunction with lime in unplanted pots (Williams et al., 1988a), and the water-soluble $\mathrm{Ca}^{2+}$ and $\mathrm{Mg}^{2+}$ concentrations that can be expected from the incorporation of dolomitic lime into a soilless medium (Argo and Biernbaum, 1996; Warncke and Krauskopf, 1983). However, it has been suggested that not all the incorporated liming material may have reacted upon reaching equilibrium (Argo and Biernbaum, 1996). The significance of residual or unreacted lime on the long-term $\mathrm{pH}$ or water-soluble $\mathrm{Ca}^{2+}$ and $\mathrm{Mg}^{2+}$ buffering capacity in soilless media containing plants has not been quantified.

Several studies have been conducted to quantify the nutrient content of different sources of irrigation water in the United States. Ludwig and Peterson (1984) found that throughout the United States, titratable alkalinity ranged from 2 to $575 \mathrm{mg} \mathrm{CaCO}_{3} /$ liter (average $147 \mathrm{mg} \cdot \mathrm{liter}^{-1}$ ); electrical conductivity (EC), from 0 to 6.5 $\mathrm{dS} \cdot \mathrm{m}^{-1}$ (average $0.5 \mathrm{dS} \cdot \mathrm{m}^{-1}$ ); $\mathrm{Ca}^{2+}$, from 0 to $440 \mathrm{mg} \cdot$ liter $^{-1}$ (average $60 \mathrm{mg} \cdot \mathrm{liter}^{-1}$ ); $\mathrm{Mg}^{2+}$, from 0 to $300 \mathrm{mg} /$ liter (average $20 \mathrm{mg} \cdot \mathrm{liter}^{-1}$ ); and $\mathrm{Na}^{+}$, from 0 to $1150 \mathrm{mg} \cdot \mathrm{liter}^{-1}$ (average $35 \mathrm{mg} \cdot \mathrm{liter}^{-1}$ ), based on 687 water samples from the greenhouse industry. Reddy et al. (1994) found that only $11 \%$ of the IWSs tested contained sufficient concentrations of $\mathrm{SO}_{4}-\mathrm{S}\left(30 \mathrm{mg} \cdot \mathrm{liter}^{-1}\right)$ recommended for plant growth in container culture.

Different IWS require different types of management (Bunt, 1988; Nelson, 1991; Vetanovetz and Hulme, 1991). Irrigation water containing large amounts of bicarbonate alkalinity $(>250 \mathrm{mg}$ $\mathrm{CaCO}_{3}$ /liter) commonly are treated by adding strong mineral acid $\left(\mathrm{HNO}_{3}, \mathrm{H}_{2} \mathrm{SO}_{4}\right.$, or $\left.\mathrm{H}_{3} \mathrm{PO}_{4}\right)$. Researchers recommend adding suffi- 
cient acid to reduce the alkalinity to 100 to $120 \mathrm{mg} \mathrm{CaCO} /$ liter or reduce the solution $\mathrm{pH}$ to 6.0 to 6.5 (Bunt, 1988; Nelson, 1991; Spurway and Wildon, 1938). Alternative sources such as rainwater or reverse osmosis (RO) purified water are gaining popularity because of their low alkalinity (Biernbaum, 1992). However, rainwater and $\mathrm{RO}$ water contain minimal nutrients.

The type of WSF applied to a root medium affects $\mathrm{pH}$ and nutrient concentrations two ways: directly, by nutrients applied to the root medium, and indirectly, by acidification of the rhizosphere $\mathrm{pH}$. Fertilization with $\mathrm{NO}_{3}^{-}-\mathrm{N}$ causes the medium $\mathrm{pH}$ to increase because of $\mathrm{OH}^{-}$or $\mathrm{HCO}_{3}^{-}$secretion associated with balancing ion uptake. In comparison, fertilization with $\mathrm{NH}_{4}^{+}-\mathrm{N}$ causes the medium $\mathrm{pH}$ to decrease because of $\mathrm{H}^{+}$secretion during root uptake and nitrification of the $\mathrm{NH}_{4}^{+}-\mathrm{N}$ to the $\mathrm{NO}_{3}^{-}-\mathrm{N}$ form, which also releases $\mathrm{H}^{+}$(Barker and Mills, 1980; Bunt, 1988; Hawkes et al., 1985; Marschner, 1986; Nelson, 1991; Vetanovetz and Hulme, 1991).

Many commercially available WSFs contain a high percentage of $\mathrm{NH}_{4}^{+}-\mathrm{N}$ and $\mathrm{PO}_{4}-\mathrm{P}$ but little $\mathrm{Mg}^{2+}$ and no $\mathrm{Ca}^{2+}$ [examples: Peter's 21-7-7 Acid Special, $100 \% \mathrm{NH}_{4}^{+}-\mathrm{N}, 0.05 \% \mathrm{Mg}^{2+}, 0 \% \mathrm{Ca}^{2+}$; Peter's 20-20-20 General Purpose, 72\% $\mathrm{NH}_{4}^{+}-\mathrm{N}, 0.05 \% \mathrm{Mg}^{2+}, 0 \% \mathrm{Ca}^{2+}$; Peter's 20-10-20 Peatlite Special, 40\% $\mathrm{NH}_{4}^{+}-\mathrm{N}, 0.05 \% \mathrm{Mg}^{2+}, 0 \%$ $\mathrm{Ca}^{2+}$ (Peter's Fertilizer; Scotts, Marysville, Ohio). Because of the high $\mathrm{NH}_{4}^{+}-\mathrm{N}$ content, the reaction produced by these WSFs are acidic $[21-7-7=780 \mathrm{~kg}$ acidity $/ 1000 \mathrm{~kg}, 20-20-20=300 \mathrm{~kg}$ acidity $/ 1000 \mathrm{~kg}, 20-10-20=210 \mathrm{~kg}$ acidity $/ 1000 \mathrm{~kg}$ (Peter's Fertilizer)]. In comparison, WSF that produce neutral or basic reactions in the root medium are typically low in $\mathrm{NH}_{4}^{+}-\mathrm{N}$ and $\mathrm{PO}_{4}^{-}$ $\mathrm{P}$ but high in $\mathrm{Ca}^{2+}$ and $\mathrm{NO}_{3}{ }^{-} \mathrm{N}$ (examples: Peter's 19-0-16 Western Greenhouse Formula, 24\% $\mathrm{NH}_{4}^{+}-\mathrm{N}, 6.5 \% \mathrm{Ca}^{2+}, 15 \mathrm{~kg}$ acidity/1000 kg; Excel 15-5-15, 28\% $\mathrm{NH}_{4}^{+}-\mathrm{N}, 12 \% \mathrm{Ca}^{2+}, 68 \mathrm{~kg}$ basicity/1000 kg; Peter's 15-0-15 Dark Weather Special, 13\% $\mathrm{NH}_{4}^{+}-\mathrm{N}, 14 \% \mathrm{Ca}^{2+}, 210 \mathrm{~kg}$ basicity/1000 kg).

Emphasis needs to be placed on designing a WSF program for container plant production based on a given medium and IWS (Biernbaum, 1992; Vetanovetz and Knauss, 1988). However, these proposed strategies have not been tested under controlled conditions. The objectives of this experiment were to determine how lime, IWS, and WSF interact to affect the management of root-medium $\mathrm{pH}$ and medium and shoot-tissue macronutrient concentrations over time.

\section{Materials and Methods}

The experiment included 24 treatments composed of two types of lime, four types of IWSs, and three types of WSFs combined in a $2 \times 4 \times 3$ factorial arrangement. At each sampling date, four pots from each treatment (two pots from each of two greenhouse sections) were sampled. Replication was made between greenhouse sections, while the two pots taken from the same greenhouse section were treated as subsamples for the statistical analysis.

Soil test data were analyzed using SAS's analysis of variance (ANOVA) procedures (SAS Institute, Cary, N.C.) as a $2 \times 4 \times 3$ split-plot factorial with lime as the main plot and the other factors as subplots at each sampling date. Medium EC and nutrient concentration data were transformed to $\log ($ observed +1$)$ for the ANOVA because of differences in sample variance between treatments. Time was not included in the ANOVA because sample variance changed over time.

Because of the factorial arrangement of the experiment, a range of $\mathrm{Ca}^{2+}, \mathrm{Mg}^{2+}$, and $\mathrm{SO}_{4}-\mathrm{S}$ concentrations in the nutrient solutions, as well as a range of medium $\mathrm{pH}$ values were obtained with the different treatments. Relationships were developed between the concentration of $\mathrm{Ca}^{2+}$ and $\mathrm{Mg}^{2+}$ in the applied nutrient solutions and tissue $\mathrm{Ca}$ and $\mathrm{Mg}$ using SAS's linear regression procedure (REG). Relationships also were developed between the concentration of $\mathrm{SO}_{4}-\mathrm{S}$ in the nutrient solutions and the tissue $\mathrm{S}$ and rootmedium $\mathrm{pH}$ and tissue $\mathrm{P}$ using the intersecting straight line model proposed by Anderson and Nelson (1975) with multiphase functions proposed by Fisher (1995). The functions used were

$$
\begin{aligned}
& X_{\text {intersection }}=\left(I_{2}-I_{1}\right) /\left(S_{1}-S_{2}\right) \\
& \text { If: } X<X_{\text {intersection, }} \text { then, } Y=S_{1} X+I_{1} \\
& \text { If: } X>X_{\text {intersection, }} \text { then, } Y=S_{2} X+I_{2}
\end{aligned}
$$

where the $\mathrm{X}$ value is either $\mathrm{SO}_{4}-\mathrm{S}$ concentration in $\mathrm{mg} \cdot$ liter $^{-1}$ or root medium $\mathrm{pH}, \mathrm{Y}$ is tissue $\mathrm{S}$ or $\mathrm{P}$ in percent of total dry mass, $\mathrm{X}_{\text {intersection }}$ is the intersection point of the two lines where the $\mathrm{Y}$ values are equal and was calculated using Eq. [1], and S and I are the slope and $y$-intercept of Eqs. [2] and [3], respectively. Initial estimates for the parameters were obtained from a graph of the observed data. Estimates for $\mathrm{S}_{1}, \mathrm{I}_{1}, \mathrm{~S}_{2}$, and $\mathrm{I}_{2}$, based on either the applied $\mathrm{SO}_{4}-\mathrm{S}$ or root-medium $\mathrm{pH}$, were obtained using $\mathrm{SAS}$ 's nonlinear regression procedure (NLIN).

Lime. The two liming materials varied in reactivity and incorporation rate. A microfine dolomitic hydrated lime [97\% $\mathrm{Ca}(\mathrm{OH})_{2} \bullet \mathrm{MgO}$, National Lime and Stone, Findlay, Ohio] in which $92 \%$ of the material passed through a $45-\mu \mathrm{m}$ (no. 325) screen was incorporated at $1.5 \mathrm{~kg} \cdot \mathrm{m}^{-3}$. At this incorporation rate, the hydrated lime added $0.5 \mathrm{~kg} \mathrm{Ca}^{2+}, 0.3 \mathrm{~kg} \mathrm{Mg}^{2+}$, and the equivalent of $2.6 \mathrm{~kg}$ $\mathrm{CaCO}_{3} / \mathrm{m}^{3}$ to the root medium. A superfine dolomitic carbonate lime (99.5\% $\mathrm{CaCO}_{3} \cdot \mathrm{MgCO}_{3}$, National Lime and Stone) in which $65 \%$ of the material passed through a $75-\mu \mathrm{m}(\# 200)$ screen was incorporated at $8.4 \mathrm{~kg} \cdot \mathrm{m}^{-3}$. At this incorporation rate, the carbonate lime added $1.8 \mathrm{~kg} \mathrm{Ca}^{2+}, 1.1 \mathrm{~kg} \mathrm{Mg}^{2+}$, and the equivalent of $9.1 \mathrm{~kg}$ $\mathrm{CaCO}_{3} / \mathrm{m}^{3}$ to the root medium.

The root medium used was (by volume) $70 \%$ Canadian sphagnum peat (Fisons professional black bale peat, Sun Gro Horticulture, Bellevue, Wash.) with long fibers and little dust (Von Post scale 1-2; Puustjarvi and Robertson, 1975), and 30\% perlite. A preplant nutrient charge (PNC) consisting of $0.6 \mathrm{~kg}$ each of $\mathrm{Ca}\left(\mathrm{NO}_{3}\right)_{2}, \mathrm{KNO}_{3}$, triple superphosphate $(0 \mathrm{~N}-19.8 \mathrm{P}-0 \mathrm{~K})$, and gypsum; $0.3 \mathrm{~kg} \mathrm{MgSO}$; $0.07 \mathrm{~kg}$ fritted trace elements (FTE 555, Scotts, Marysville, Ohio); and 0.2 liters of a wetting agent (Aquagro 2000 L, Aquatrols, Pennsaulken, N.J.) per $\mathrm{m}^{3}$ of medium, in addition to the lime, were added at mixing. Sufficient RO water was added at mixing to bring the moisture content of the medium to $40 \%$ to $50 \%$ of container capacity, and the medium was allowed to equilibrate for three days before planting. At planting, the hydrated lime treatments had a $\mathrm{pH}$ of 6.1 , an $\mathrm{EC}$ of $2.3 \mathrm{dS} \cdot \mathrm{m}^{-1}$, and $220 \mathrm{NO}_{3}{ }^{-} \mathrm{N}, 14 \mathrm{NH}_{4}{ }^{-}-\mathrm{N}, 40 \mathrm{PO}_{4}^{-} \mathrm{P}, 200 \mathrm{~K}^{+}, 250 \mathrm{Ca}^{2+}, 185 \mathrm{Mg}^{2+}$, and $110 \mathrm{SO}_{4}-\mathrm{S}\left(\mathrm{mg} \cdot\right.$ liter $\left.^{-1}\right)$; while the carbonate lime treatments had a $\mathrm{pH}$ of 5.5, an EC of $2.6 \mathrm{dS} \cdot \mathrm{m}^{-1}$, and $220 \mathrm{NO}_{3}^{-} \mathrm{N}, 13 \mathrm{NH}_{4}^{+}$ $\mathrm{N}, 53 \mathrm{PO}_{4}-\mathrm{P}, 215 \mathrm{~K}^{+}, 230 \mathrm{Ca}^{2+}, 160 \mathrm{Mg}^{2+}$, and $95 \mathrm{SO}_{4}-\mathrm{S}\left(\mathrm{mg} \cdot \mathrm{liter}^{-1}\right)$, based on the saturated-medium extract (SME) method (Warncke and Krauskopf, 1983).

IWS. The four IWSs varied in $\mathrm{EC}, \mathrm{Ca}^{2+}, \mathrm{Mg}^{2+}, \mathrm{Na}^{+}, \mathrm{SO}_{4}-\mathrm{S}$ concentration, and alkalinity content. The high-alkalinity water source (well water) had a pH of 7.8, an EC of $0.6 \mathrm{dS} \cdot \mathrm{m}^{-1} ; 105 \mathrm{Ca}^{2+}$, $35 \mathrm{Mg}^{2+}, 12 \mathrm{Na}^{+}, 23 \mathrm{SO}_{4}-\mathrm{S}\left(\mathrm{mg} \cdot\right.$ liter $\left.^{-1}\right)$; and a titratable alkalinity to $\mathrm{pH} 4.5$ (Chau, 1984) of $320 \mathrm{mg} \mathrm{CaCO}_{3}$ /liter. The low-alkalinity water source was RO purified well water, which had a $\mathrm{pH}$ of 5.5, an EC of $0.1 \mathrm{dS} \cdot \mathrm{m}^{-1} ; 20 \mathrm{Ca}^{2+}, 7 \mathrm{Mg}^{2+}, 23 \mathrm{Na}^{+}, 1 \mathrm{SO}_{4}-\mathrm{S}\left(\mathrm{mg} \cdot \mathrm{liter}^{-1}\right.$ ); and a titratable alkalinity to $\mathrm{pH} 4.5$ of $<20 \mathrm{mg} \mathrm{CaCO} /$ liter. The third type of water (acidified water) was produced by adding $\mathrm{H}_{2} \mathrm{SO}_{4}(93 \%)$ to the well water and had a $\mathrm{pH}$ of 5.8, an EC of 0.7 


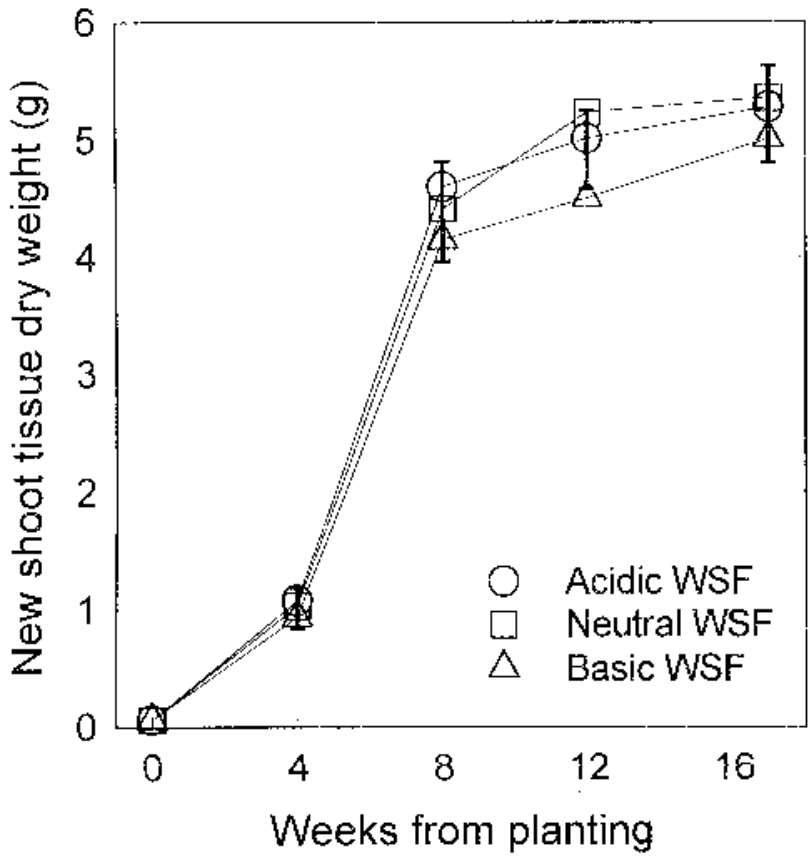

Fig. 1. Average new shoot dry weight of the three water-soluble fertilizer (WSF) treatments from impatiens at 4, 8, 12, and 17 weeks after planting. After each harvest, remaining plants were pruned to the same point. Error bars were calculated as $95 \%$ confidence intervals. Data represent only the new shoot growth from the previous 4-week period.

$\mathrm{dS} \cdot \mathrm{m}^{-1}$; concentrations of $\mathrm{Ca}^{2+}, \mathrm{Mg}^{2+}$, and $\mathrm{Na}^{+}$similar to that of the well water; $91 \mathrm{mg} \mathrm{SO}_{4}-\mathrm{S} / \mathrm{m}^{3}$; and a titratable alkalinity to $\mathrm{pH} 4.5$ of $120 \mathrm{mg} \mathrm{CaCO}_{3} /$ liter. The fourth irrigation water (well + $\mathrm{RO}$ water) was produced by blending well and $\mathrm{RO}$ water (1:1.5, by volume) and had a $\mathrm{pH}$ of 6.8 , an EC of $0.3 \mathrm{dS} \cdot \mathrm{m}^{-1} ; 56 \mathrm{Ca}^{2+}, 12 \mathrm{Mg}^{2+}, 21 \mathrm{Na}^{+}$, and $9 \mathrm{SO}_{4}-\mathrm{S}\left(\mathrm{mg} \cdot\right.$ liter $\left.^{-1}\right)$; and a titratable alkalinity to $\mathrm{pH} 4.5$ of 130 $\mathrm{mg} \mathrm{CaCO}_{3} /$ liter.

$W S F$. Fertilizer concentrations were maintained at (in $\mathrm{mg}$ ) $150 \mathrm{~N}-15 \mathrm{P}-150 \mathrm{~K} / \mathrm{liter}$ for the first 2 weeks and increased to $200 \mathrm{~N}-$ 20P-200K/liter for the remainder of the experiment. The three WSFs varied in $\mathrm{NH}_{4}^{+}-\mathrm{N}, \mathrm{Ca}^{2+}, \mathrm{Mg}^{2+}$, and $\mathrm{SO}_{4}-\mathrm{S}$ concentrations. At
$200 \mathrm{mg} \mathrm{N} /$ liter, WSF 1 contained $50 \% \mathrm{NH}_{4}^{+}-\mathrm{N}$ with $0 \mathrm{Ca}^{2+}, 0 \mathrm{Mg}^{2+}$, and $42 \mathrm{SO}_{4}-\mathrm{S}\left(\mathrm{mg} \cdot \mathrm{liter}^{-1}\right)$; WSF 2 contained $25 \% \mathrm{NH}_{4}^{+}-\mathrm{N}$ with 50 $\mathrm{Ca}^{2+}, 25 \mathrm{Mg}^{2+}$, and $35 \mathrm{SO}_{4}-\mathrm{S}\left(\mathrm{mg} \cdot \mathrm{liter}^{-1}\right)$; and WSF 3 contained $3 \%$ $\mathrm{NH}_{4}^{+}-\mathrm{N}$ with $100 \mathrm{Ca}^{2+}, 50 \mathrm{Mg}^{2+}$, and $3 \mathrm{SO}_{4}-\mathrm{S}\left(\mathrm{mg} \cdot\right.$ liter $\left.{ }^{-1}\right)$. Micronutrients ( $\mathrm{Fe}, \mathrm{Mn}, \mathrm{Zn}, \mathrm{Cu}, \mathrm{B}$, and $\mathrm{Mo}$ ) were added to all WSF treatments with a commercially available chelated material [Compound $111(1.50 \mathrm{Fe}-0.12 \mathrm{Mn}-0.08 \mathrm{Zn}-0.11 \mathrm{Cu}-0.23 \mathrm{~B}-0.11 \mathrm{Mo})$, Scotts] at a constant $50 \mathrm{mg} \cdot$ liter $^{-1}$.

The type of reaction produced by the WSF was calculated, with values for the reaction produced by the individual salts obtained from Hawkes et al. (1985) and Young and Johnson (1982) multiplied by the percentage that each salt contributed to the total WSF weight. The value obtained for each WSF was used as an estimate of the type (either acidic or basic) and strength (in kg/1000 kg of fertilizer) of reaction produced. Based on these calculations, WSF 1 (acidic WSF) had an acidity of $199 \mathrm{~kg} / 1000 \mathrm{~kg}$, WSF 2 (neutral WSF) had a basicity of $8 \mathrm{~kg} / 1000 \mathrm{~kg}$, and WSF 3 (basic WSF) had a basicity of $175 \mathrm{~kg} / 1000 \mathrm{~kg}$.

Plant culture. The experiment was conducted starting $15 \mathrm{Feb}$. 1994 at Michigan State Univ., East Lansing, in two well-ventilated glass greenhouse sections with constant air circulation and cement floors. One hybrid impatiens plug ('Super Elfin Violet') from a size 512 plug tray was planted into a 9 -cm-tall $\times 12.5$-cm-wide (0.75-liter) plastic pot containing medium with one of the two lime types. Twenty-five pots containing medium with each lime type were placed on one of twelve flood subirrigation bench sections in each of the two greenhouses. Both lime types were placed on the same bench section.

Plants on each bench section were irrigated as needed. The time to irrigate was determined gravimetrically when the average mass of six randomly selected pots containing plants and medium (three from each lime treatment) reached a target weight based on a loss of $40 \%$ to $50 \%$ of the available water. The same six pots were checked daily for the target weight, and when it was reached, nutrient solutions were applied. During an irrigation, benches were filled from a 70-liter reservoir for 2 min to a maximum depth of 2.5 $\mathrm{cm}$ and drained in $6 \mathrm{~min}$ to the same reservoir. The difference between the mass of the pots before and after the irrigation was the amount of water absorbed by the medium. The amount of nutrients applied per pot was calculated as the sum of the absorbed nutrient

Table 1. Cumulative water, $\mathrm{Ca}^{2+}, \mathrm{Mg}^{2+}$, and $\mathrm{SO}_{4}-\mathrm{S}$ applied with the various irrigation-water source (IWS) and water-soluble fertilizer (WSF) treatments after 17 weeks. The initial nutrient content of the root medium was not included in the values reported below but was $0.7 \mathrm{~g} \mathrm{Ca}^{2+}, 0.3 \mathrm{~g} \mathrm{Mg}^{2+}$, and $0.1 \mathrm{~g} \mathrm{SO}_{4}-\mathrm{S}$ per pot with the hydrated lime treatments and $1.5 \mathrm{~g} \mathrm{Ca}^{2+}, 0.8 \mathrm{~g} \mathrm{Mg}^{2+}$, and $0.1 \mathrm{~g} \mathrm{SO}_{4}-\mathrm{S}_{\text {per }}$ pot with the carbonate lime treatment. Data are the mean of six pots. Statistical analysis indicates a three-way interaction with $>0.01$ significance for all four variables measured.

\begin{tabular}{|c|c|c|c|c|c|c|c|c|c|}
\hline \multirow[b]{2}{*}{ IWS } & \multirow[b]{2}{*}{ WSF } & \multicolumn{4}{|c|}{ Hydrated lime } & \multicolumn{4}{|c|}{ Carbonate lime } \\
\hline & & $\begin{array}{l}\text { Applied } \\
\text { water } \\
\text { (liters) }\end{array}$ & $\begin{array}{c}\mathrm{Ca}^{2+} \\
(\mathrm{g} / \mathrm{pot})\end{array}$ & $\begin{array}{c}\mathrm{Mg}^{2+} \\
\text { (g/pot) }\end{array}$ & $\begin{array}{l}\mathrm{SO}_{4}-\mathrm{S} \\
(\mathrm{g} / \mathrm{pot})\end{array}$ & $\begin{array}{l}\text { Applied } \\
\text { water } \\
\text { (liters) }\end{array}$ & $\begin{array}{c}\mathrm{Ca}^{2+} \\
\text { (g/pot) }\end{array}$ & $\begin{array}{l}\mathrm{Mg}^{2+} \\
\text { (g/pot) }\end{array}$ & $\begin{array}{l}\mathrm{SO}_{4}-\mathrm{S} \\
\text { (g/pot) }\end{array}$ \\
\hline$\overline{\text { Well }}$ & Acidic & 7.8 & 0.8 & 0.3 & 0.6 & 8.1 & 0.9 & 0.3 & 0.7 \\
\hline Well & Neutral & 7.7 & 1.3 & 0.5 & 0.6 & 7.4 & 1.2 & 0.4 & 0.6 \\
\hline Well & Basic & 7.2 & 1.6 & 0.6 & 0.3 & 7.6 & 1.6 & 0.7 & 0.3 \\
\hline Acidified & Acidic & 8.3 & 0.8 & 0.3 & 1.2 & 8.0 & 0.8 & 0.3 & 1.2 \\
\hline Acidified & Neutral & 7.8 & 1.2 & 0.5 & 1.1 & 7.5 & 1.1 & 0.5 & 1.1 \\
\hline Acidified & Basic & 7.4 & 1.5 & 0.7 & 0.8 & 7.5 & 1.5 & 0.7 & 0.8 \\
\hline Well + $\mathrm{RO}^{\mathrm{z}}$ & Acidic & 8.7 & 0.5 & 0.1 & 0.6 & 8.1 & 0.5 & 0.1 & 0.5 \\
\hline Well + RO & Neutral & 8.4 & 0.9 & 0.3 & 0.5 & 8.1 & 0.9 & 0.3 & 0.5 \\
\hline Well + RO & Basic & 8.2 & 1.4 & 0.5 & 0.2 & 8.2 & 1.4 & 0.5 & 0.2 \\
\hline RO & Acidic & 8.9 & 0.2 & 0.1 & 0.5 & 7.8 & 0.2 & 0.1 & 0.5 \\
\hline RO & Neutral & 8.4 & 0.6 & 0.3 & 0.5 & 8.2 & 0.6 & 0.3 & 0.4 \\
\hline RO & Basic & 7.8 & 1.0 & 0.5 & 0.1 & 7.8 & 1.0 & 0.5 & 0.1 \\
\hline
\end{tabular}


solution multiplied by the concentration applied for each irrigation. The nutrient solutions in the 70-liter reservoirs were emptied and prepared fresh weekly.

Root media were sampled initially and collected from four pots (two per treatment from each bench section) at 1, 4, 8, 12, and 17 weeks after planting. All the medium was removed from each pot and separated horizontally into two samples, one containing the top $2.5 \mathrm{~cm}$ (top layer), and the other containing the remaining medium from the pot (root zone). Nutrients contained in each media sample were tested using the SME method with RO purified water as the extractant (Warncke, 1986). Only EC was measured in the top layer sample, while $\mathrm{pH}, \mathrm{EC}, \mathrm{NO}_{3}{ }^{-} \mathrm{N}$ and $\mathrm{NH}_{4}{ }^{+}-\mathrm{N}, \mathrm{PO}_{4}^{-}$ $\mathrm{P}, \mathrm{K}^{+}, \mathrm{Ca}^{2+}, \mathrm{Mg}^{2+}$, and $\mathrm{SO}_{4}-\mathrm{S}$ were measured in the root zone sample. Medium $\mathrm{pH}$ was determined by inserting the $\mathrm{pH}$ electrode directly into the saturated medium before extraction, and EC and macronutrients were measured in the extracted solution. Medium EC was determined with a platinum electrode at a standard 25C. Nitrate N (Diamond, 1986a), $\mathrm{NH}_{4}^{+}-\mathrm{N}$ (Diamond, 1986b), $\mathrm{PO}_{4} \mathrm{r} P$ (Bloxham, 1990), $\mathrm{Mg}^{2+}$ (magnesium blue, Technicon Instruments, Tarrytown, N.Y.), and $\mathrm{SO}_{4}-\mathrm{S}$ (McKnight, 1991) were determined colorimetrically. Medium $\mathrm{K}^{+}$and $\mathrm{Ca}^{2+}$ were determined by the Michigan State Univ. Soil and Nutrient Testing Laboratory using emission spectroscopy.

Shoot fresh and dry weight and tissue nutrient analysis were determined for four plants per treatment at $4,8,12$, and 17 weeks after planting. At week 4, the entire plant was used in the sample. For the remaining plants, all shoots were pinched back, leaving one internode per stem and four to six stems per plant. At all subsequent sampling dates, only growth after the previous pinch was sampled, and the remaining plants were cut back to the week 4 pinch level. Shoot $\mathrm{N}$ and $\mathrm{S}$ were determined by column chromatography, and shoot $\mathrm{P}, \mathrm{K}, \mathrm{Ca}$, and $\mathrm{Mg}$ were determined by plasma emission spectroscopy (Fafard Analytical Laboratory, Athens, Ga.).

\section{Results and Discussion}

Plant growth. In general, the experimental treatments affected shoot growth of impatiens minimally (Fig. 1). The average dry mass of the stem below the pinched material was $1.9 \mathrm{~g}$ at the end of the experiment (data not shown). Averaged over all treatments, a total of $17.5 \mathrm{~g}$ of shoot dry mass was produced over the 17 weeks of the experiment.

In many experiments, plant shoot tissue is sampled sequentially over time or at the end of the experiment (Adams et al.; 1978; Argo and Biernbaum, 1994; Argo and Biernbaum, 1996, Yelanich, 1995; Yelanich and Biernbaum, 1993). Determining changes in nutrient availability over time is difficult because the nutrient content of the shoot tissue represent the sum of the conditions under which the growth occurred. Cutting the plants back at 4 -week intervals left minimal shoot tissue that could be used as a nutrient reservoir for mobile macronutrients $(\mathrm{N}, \mathrm{P}, \mathrm{K}, \mathrm{Mg}$ ) while sampling only the new growth tested the ability of the plants to take up mobile and immobile macronutrients $(\mathrm{Ca}, \mathrm{S})$ over the 4 -week period. Therefore, there should have been a better correlation between the availability of nutrients in the root medium and tissue nutrient concentrations over the 4-week period than if the plants were allowed to grow from planting until the sampling date, as typically has been done.

Water and fertilizer applications. The volume of nutrient solutions applied ranged from 7.2 to 8.9 liters/pot over the 17 weeks of

Fig. 2. Root-medium pH, electrical conductivity (EC), $\mathrm{PO}_{4}^{-} \mathrm{P}, \mathrm{Ca}^{2+}, \mathrm{Mg}^{2+}$, and $\mathrm{SO}_{4}^{-}$ $\mathrm{S}$ concentrations in the root zone of plants grown with four irrigation-water sources between weeks 1 and 17. Filled symbols are hydrated lime treatments and hollow symbols are carbonate lime treatments with acidic water-soluble fertilizer (WSF) ( and $\bigcirc$ ), neutral WSF ( $\square$ and $\square)$, and basic WSF ( $\nabla$ and $\nabla)$. The dotted lines (...) represent the recommended optimal ranges the and dashed lines (---) represent the lower recommended acceptable range for the saturated media extract (Warncke and Krauskopf, 1983). Statistical analysis is presented in Table 2 : Bata are means of four samples at each date:
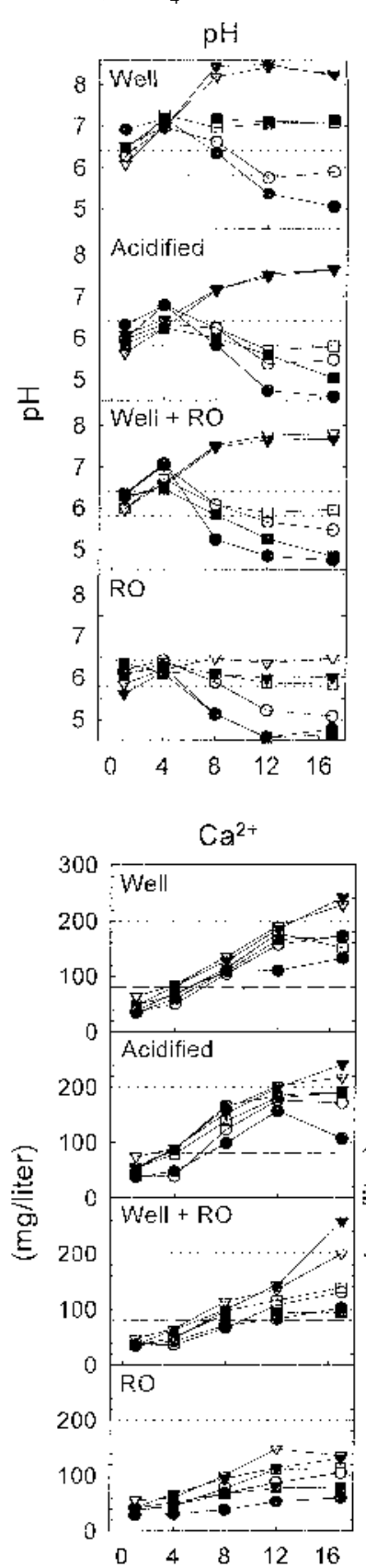
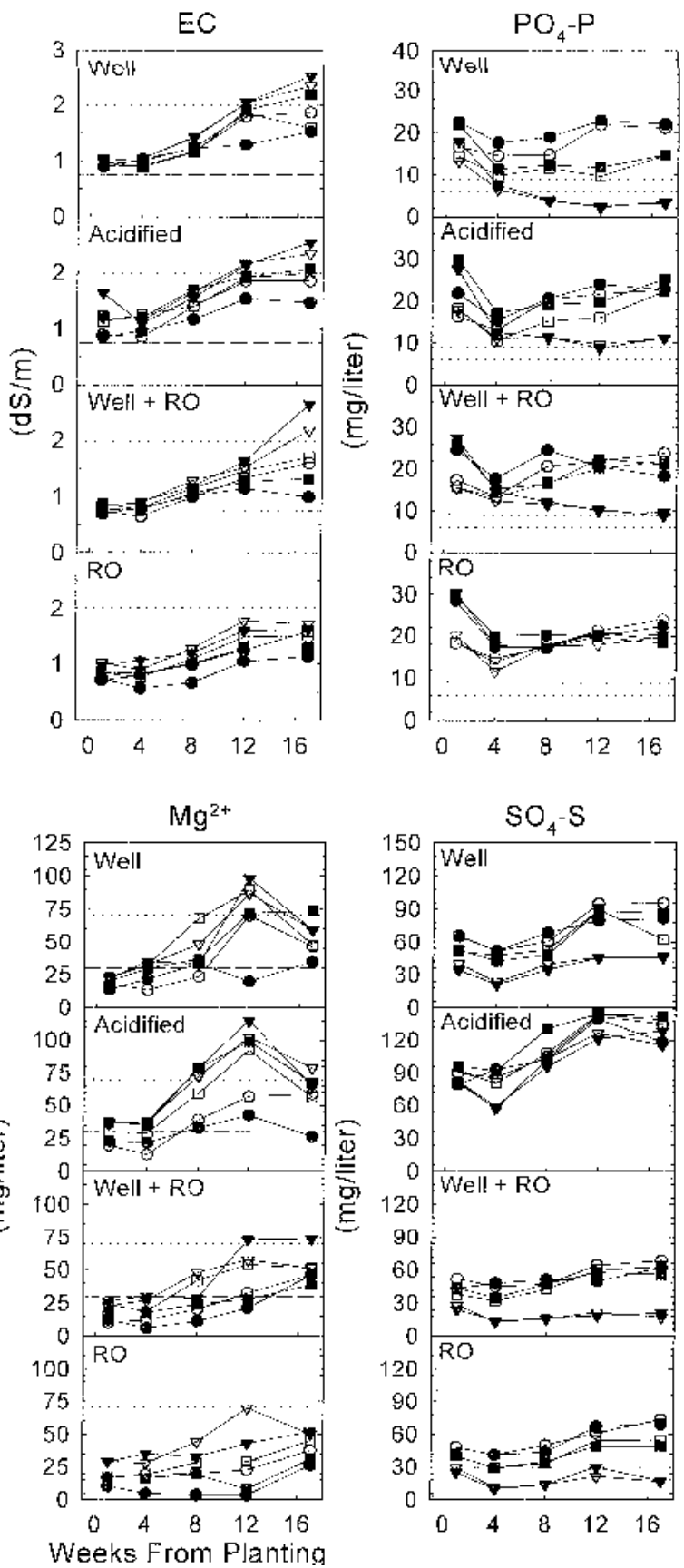


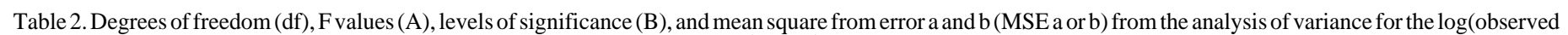
+1 ) transformed root-medium $\mathrm{pH}$, electrical conductivity (EC), $\mathrm{PO}_{4}-\mathrm{P}, \mathrm{Ca}^{2+}, \mathrm{Mg}^{2+}$, and $\mathrm{SO}_{4}-\mathrm{S}$ concentrations at $1,4,8,12$, and 17 weeks after planting.

\begin{tabular}{|c|c|c|c|c|c|c|c|c|c|c|c|}
\hline & \multirow[b]{2}{*}{$\mathrm{df}$} & \multicolumn{2}{|c|}{ Week 1} & \multicolumn{2}{|c|}{ Week 4} & \multicolumn{2}{|c|}{ Week 8} & \multicolumn{2}{|c|}{ Week 12} & \multicolumn{2}{|c|}{ Week 17} \\
\hline & & A & $\mathrm{B}$ & A & $\mathrm{B}$ & A & $\mathrm{B}$ & A & $\mathrm{B}$ & A & $\mathrm{B}$ \\
\hline \multicolumn{12}{|c|}{$p H$} \\
\hline Lime (L) & 1 & 14.7 & NS & 0.4 & NS & 162.0 & $*$ & 972.6 & $*$ & 32.5 & NS \\
\hline MSEa & 1 & \multicolumn{2}{|c|}{0.0002} & \multicolumn{2}{|c|}{0.0005} & \multicolumn{2}{|c|}{0.0001} & \multicolumn{2}{|c|}{0.0001} & \multicolumn{2}{|c|}{0.0001} \\
\hline IWS $^{z}$ & 3 & 13.1 & *** & 33.6 & $* * *$ & 81.1 & $* * *$ & 40.9 & $* * *$ & 61.0 & $* * *$ \\
\hline $\mathrm{L} \times \mathrm{IWS}$ & 3 & 2.5 & NS & 0.5 & NS & 6.8 & $* * *$ & 2.7 & NS & 1.8 & NS \\
\hline $\mathrm{WSF}^{\mathrm{y}}$ & 2 & 10.5 & $* * *$ & 7.9 & $* * *$ & 155.7 & $* * *$ & 170.6 & $* * *$ & 323.0 & $* * *$ \\
\hline $\mathrm{L} \times \mathrm{WSF}$ & 2 & 0.1 & NS & 1.0 & NS & 6.3 & $* * *$ & 3.7 & $*$ & 9.1 & $* * *$ \\
\hline $\mathrm{IWS} \times \mathrm{WSF}$ & 6 & 1.4 & NS & 2.1 & NS & 4.5 & $* *$ & 4.4 & $* * *$ & 11.6 & $* * *$ \\
\hline $\mathrm{L} \times \mathrm{IWS} \times \mathrm{WSF}$ & 6 & 2.1 & NS & 0.2 & NS & 0.9 & NS & 0.9 & NS & 3.1 & $* *$ \\
\hline $\mathrm{MSEb}$ & 70 & \multicolumn{2}{|c|}{0.0003} & \multicolumn{2}{|c|}{$\begin{array}{c}0.0003 \\
E C\end{array}$} & \multicolumn{2}{|c|}{0.0004} & & & 0 & \\
\hline Lime (L) & 1 & 15.2 & NS & 0.2 & NS & 1.6 & NS & 2.1 & NS & 9.4 & NS \\
\hline MSEa & 1 & & & & & & & & & & \\
\hline IWS & 3 & 24.2 & $* * *$ & 16.4 & $* * *$ & 35.9 & $* * *$ & 28.1 & $* * *$ & 21.6 & $* * *$ \\
\hline $\mathrm{L} \times \mathrm{IWS}$ & 3 & 0.8 & NS & 0.1 & NS & 1.4 & NS & 0.2 & NS & 2.8 & $*$ \\
\hline WSF & 2 & 21.2 & $* * *$ & 11.3 & $* * *$ & 27.9 & $* * *$ & 26.4 & $* * *$ & 54.8 & $* * *$ \\
\hline $\mathrm{L} \times \mathrm{WSF}$ & 2 & 0.7 & NS & 0.4 & NS & 1.4 & NS & 3.0 & NS & 11.6 & $* * *$ \\
\hline $\mathrm{IWS} \times \mathrm{WSF}$ & 6 & 2.5 & $*$ & 2.0 & NS & 1.7 & NS & 0.3 & NS & 2.9 & $*$ \\
\hline $\mathrm{L} \times \mathrm{IWS} \times \mathrm{WSF}$ & 6 & 0.9 & NS & 1.8 & NS & 2.1 & NS & 0.7 & NS & 1.8 & NS \\
\hline $\mathrm{MSEb}$ & 70 & & & & & & & & & 0 & \\
\hline Lime (L) & 1 & 1633.6 & $*$ & 97.9 & NS & 30.6 & NS & 0.4 & NS & 0.0 & NS \\
\hline MSEa & 1 & & & & & & & & & & \\
\hline IWS & 3 & 48.1 & $* * *$ & 27.2 & $* * *$ & 94.8 & $* * *$ & 118.7 & $* * *$ & 25.2 & $* * *$ \\
\hline $\mathrm{L} \times \mathrm{IWS}$ & 3 & 3.9 & $* *$ & 1.6 & NS & 0.6 & NS & 0.3 & NS & 0.3 & NS \\
\hline WSF & 2 & 1.0 & NS & 29.6 & $* * *$ & 167.6 & $* * *$ & 303.2 & $* * *$ & 80.2 & $* * *$ \\
\hline $\mathrm{L} \times \mathrm{WSF}$ & 2 & 4.5 & $* *$ & 0.0 & NS & 0.7 & NS & 1.5 & NS & 0.5 & NS \\
\hline $\mathrm{IWS} \times \mathrm{WSF}$ & 6 & 8.9 & $* * *$ & 9.6 & $* * *$ & 33.1 & $* * *$ & 56.4 & $* * *$ & 12.6 & $* * *$ \\
\hline $\mathrm{L} \times \mathrm{IWS} \times \mathrm{WSF}$ & 6 & 1.0 & NS & 0.6 & NS & 1.2 & NS & 1.3 & NS & 0.2 & NS \\
\hline $\mathrm{MSEb}$ & 70 & & & & & & & & & & \\
\hline Lime (L) & 1 & 34.6 & NS & 0.6 & NS & 1.7 & NS & 3.4 & NS & 958.6 & $*$ \\
\hline MSEa & 1 & & & & & & & & & & \\
\hline IWS & 3 & 5.2 & $* *$ & 21.9 & $* * *$ & 88.1 & $* * *$ & 56.9 & $* * *$ & 66.7 & $* * *$ \\
\hline $\mathrm{L} \times \mathrm{IWS}$ & 3 & 0.5 & NS & 1.6 & NS & 3.2 & NS & 2.9 & NS & 2.7 & NS \\
\hline WSF & 2 & 13.7 & $* * *$ & 60.3 & $* * * 61.3$ & & $* * *$ & 30.9 & $* * *$ & 90.6 & $* * *$ \\
\hline $\mathrm{L} \times \mathrm{WSF}$ & 2 & 2.2 & NS & 0.0 & NS & 2.2 & NS & 3.5 & NS & 16.8 & $* * *$ \\
\hline $\mathrm{IWS} \times \mathrm{WSF}$ & 6 & 0.5 & NS & 2.7 & $* *$ & 3.9 & $* *$ & 2.0 & NS & 3.7 & $* *$ \\
\hline $\mathrm{L} \times \mathrm{IWS} \times \mathrm{WSF}$ & 6 & 0.4 & NS & 2.2 & NS & 3.1 & $*$ & 0.3 & NS & 2.2 & NS \\
\hline $\mathrm{MSEb}$ & 70 & & & & & & & & & & \\
\hline Lime (L) & 1 & 18.6 & NS & 1.0 & NS & 13.4 & NS & 2362.0 & $*$ & 12.1 & NS \\
\hline MSEa & 1 & 0 & & & & & & & & 0 & \\
\hline IWS & 3 & 11.7 & $* * *$ & 18.5 & $* * *$ & 38.1 & $* * *$ & 114.2 & $* * *$ & 10.9 & $* * *$ \\
\hline $\mathrm{L} \times \mathrm{IWS}$ & 3 & 1.4 & $\mathrm{NS}$ & 5.8 & $*$ & 5.5 & $*$ & 17.8 & $* * *$ & 3.2 & $*$ \\
\hline WSF & 2 & 26.0 & $* * *$ & 80.5 & $* * *$ & 49.2 & $* * *$ & 117.9 & $* * *$ & 28.5 & $* * *$ \\
\hline $\mathrm{L} \times \mathrm{WSF}$ & 2 & 0.4 & NS & 3.8 & NS & 0.5 & NS & 21.8 & $* * *$ & 6.4 & $* *$ \\
\hline $\mathrm{IWS} \times \mathrm{WSF}$ & 6 & 1.5 & NS & 1.8 & NS & 2.8 & NS & 8.9 & $* * *$ & 1.9 & NS \\
\hline $\mathrm{L} \times \mathrm{IWS} \times \mathrm{WSF}$ & 6 & 1.1 & NS & 6.1 & $* *$ & 4.2 & $*$ & 2.9 & $* *$ & 5.9 & $* *$ \\
\hline $\mathrm{MSEb}$ & 70 & & & 0 & & & & & & 0 & \\
\hline Lime (L) & 1 & 8.2 & NS & 53.2 & NS & 0.4 & NS & 5.1 & NS & 0.0 & NS \\
\hline MSEa & 1 & & & & & & & & & & \\
\hline IWS & 3 & 133.7 & $* * *$ & 404.6 & $* * *$ & 366.3 & $* * *$ & 177.8 & $* * *$ & 332.7 & $* * *$ \\
\hline $\mathrm{L} \times \mathrm{IWS}$ & 3 & 0.4 & NS & 1.9 & NS & 0.5 & NS & 1.3 & NS & 0.5 & NS \\
\hline WSF & 2 & 56.5 & $* * *$ & 504.0 & $* * *$ & 199.8 & $* * *$ & 112.1 & $* * *$ & 294.1 & $* * *$ \\
\hline $\mathrm{L} \times \mathrm{WSF}$ & 2 & 3.2 & $*$ & 0.9 & NS & 1.0 & NS & 0.6 & NS & 3.5 & NS \\
\hline $\mathrm{IWS} \times \mathrm{WSF}$ & 6 & 5.1 & $* * *$ & 21.1 & $* * *$ & 27.0 & $* * *$ & 9.8 & $* * *$ & 40.0 & $* * *$ \\
\hline $\mathrm{L} \times \mathrm{IWS} \times \mathrm{WSF}$ & 6 & 0.5 & NS & 0.3 & NS & 1.2 & NS & 0.7 & NS & 2.0 & $*$ \\
\hline $\mathrm{MSEb}$ & 70 & & & & & & & & & & \\
\hline
\end{tabular}

${ }^{\text {ZIrrigation-water source. }}$

yWater-soluble fertilizer.

Ns,*,**,*** Nonsignificant or significant at $P \leq 0.05,0.01$, or 0.001 , respectively. 


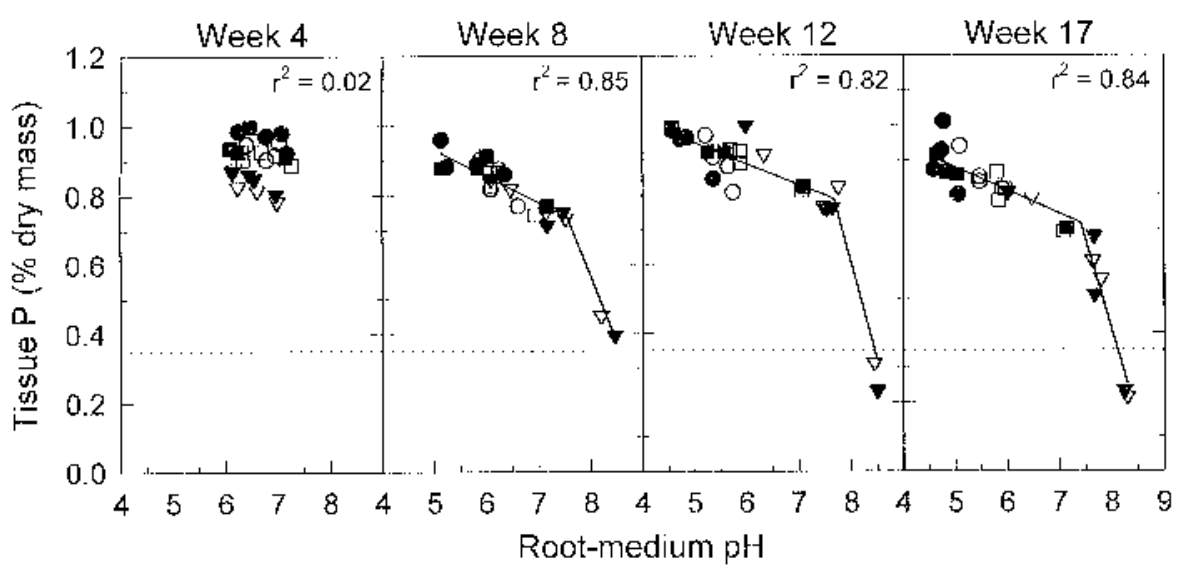

the experiment (Table 1). The volume of water applied to the impatiens in this experiment was similar to that required by other species for their normal production schedule (Argo and Biernbaum, 1994; Argo and Biernbaum, 1995b; Yelanich, 1995; Yelanich and Biernbaum, 1993).

Because the N-P-K concentrations in the WSFs were constant, the amount applied was similar and ranged from 1.5 to $1.8 \mathrm{~g} \mathrm{~N}, 0.15$ to $0.20 \mathrm{~g} \mathrm{PO}_{4}-\mathrm{P}$, and 1.5 to $1.8 \mathrm{~g} \mathrm{~K}^{+}$per pot (data not shown). In addition, $0.1 \mathrm{~g} \mathrm{~N}, 0.1 \mathrm{~g} \mathrm{PO}_{4}-\mathrm{P}$, and $0.2 \mathrm{~g} \mathrm{~K}^{+}$per pot were incorporated initially with the PNC fertilizers. In comparison, the concentrations of $\mathrm{Ca}^{2+}, \mathrm{Mg}^{2+}$, and $\mathrm{SO}_{4}-\mathrm{S}$ in the nutrient solutions varied by a factor of about 10 . The amount applied ranged from 0.2 to $1.6 \mathrm{~g} \mathrm{Ca}^{2+}, 0.1$ to $0.7 \mathrm{~g} \mathrm{Mg}^{2+}$, and 0.1 to $1.2 \mathrm{~g} \mathrm{SO}_{4}-\mathrm{S}$ per pot (Table 1). In addition to the nutrient solutions applied, hydrated lime treatments received $0.7 \mathrm{~g} \mathrm{Ca}^{2+}, 0.3 \mathrm{~g} \mathrm{Mg}^{2+}$, and $0.1 \mathrm{~g} \mathrm{SO}_{4}-\mathrm{S}$ per pot, and the carbonate lime treatments received $1.5 \mathrm{~g} \mathrm{Ca}^{2+}, 0.8 \mathrm{~g} \mathrm{Mg}^{2+}$, and $0.1 \mathrm{~g} \mathrm{SO}_{4}-\mathrm{S}$ per pot with the initial incorporation of the lime and PNC fertilizers.

Based on the mass of shoot tissue produced, sufficient nutrients were applied to all treatments to maintain tissue nutrient concentrations at levels recommended by Fortney and Wolf (1981) for floriculture crops. For example, a constant $2 \%$ tissue $\mathrm{Ca}$ content would have required about $0.35 \mathrm{~g} \mathrm{Ca}^{2+} /$ pot from the root media. The minimum amount of $\mathrm{Ca}^{2+}$ applied to a single treatment throughout the experiment was $0.9 \mathrm{~g} \mathrm{Ca}^{2+} /$ pot.

Root-zone $\mathrm{pH}$. By week 4, root-medium $\mathrm{pH}$ was similar for both lime treatments (Fig. 2, Table 2). Because of the highly reactive nature and small particle size of the hydrated lime, most of the material probably had reacted by week 4 . Assuming that similar equivalents of lime were required to obtain the same root-medium $\mathrm{pH}$, about $6 \mathrm{~kg}$ of the carbonate lime $/ \mathrm{m}^{3}$ of medium, or $4.5 \mathrm{~g} / \mathrm{pot}$, remained unreacted at the week 4 analysis.

After 8 weeks, the root-zone $\mathrm{pH}$ ranged from 4.5 to 8.5 within
Fig. 3. The effect of root-medium $\mathrm{pH}$ on the tissue $\mathrm{P}$ of impatiens at 4,8,12, and 17 weeks after planting. Filled symbols are hydrated lime treatments and hollow symbols are carbonate lime treatments with acidic water-soluble fertilizer(WSF) ( and $\bigcirc$ ), neutral WSF ( $\square$ and $\square$ ), and basic WSF $(\nabla$ and $\nabla)$. The solid line $(-)$ represents the predicted tissue $\mathrm{P}$ concentration based on Eq. [1] and the dotted line (.....) represents the minimum recommended tissue $\mathrm{P}$ concentration. $R^{2}$ values were calculated as 1 $\mathrm{SS}_{\text {residual }} / \mathrm{SS}_{\text {corrected total }}$ and remaining statistical analyses of the individual parameters are presented in Table 3. Data are means of four samples at each date.

the various treatments (Fig. 2, Table 2). Over the remaining 9 weeks of the experiment, rootzone $\mathrm{pH}$ was unaffected by lime type with $\mathrm{Ca}^{2+}$ concentrations in the nutrient solution $>150 \mathrm{mg} \cdot$ liter $^{-1}$ and root-medium $\mathrm{pH}>6.4$ (Fig. 2, Table 2). In comparison, the root-medium $\mathrm{pH}$ was higher in the carbonate lime treatments than in the hydrated lime treatments with $\mathrm{Ca}^{2+}$ concentrations in the nutrient solution $<150 \mathrm{mg} \cdot \mathrm{liter}^{-1}$ and root-medium $\mathrm{pH}<6.0$. The largest difference was measured in the RO water/ neutral WSF treatment in which the carbonate lime treatment maintained a root-medium $\mathrm{pH}$ of $6.1,5.9$, and 5.8; the hydrated lime treatment, 5.1, 4.6, and 4.6 at weeks 8, 12, and 17, respectively. These values indicate that there were considerable amounts of unreacted carbonate lime in the root medium at week 4, which greatly increased the $\mathrm{pH}$ buffering capacity of the root medium under acidifying conditions.

The effect of the WSF reaction on root-medium $\mathrm{pH}$ also depended on the alkalinity of the IWS. In general, IWSs with similar alkalinity levels had a similar root-medium $\mathrm{pH}$ throughout the experiment (Fig. 2, Table 2). The root-medium $\mathrm{pH}$ range obtained with well water was larger than that with RO water. Thus, if general guidelines for using WSFs to manage $\mathrm{pH}$ in container media are to be based on the reaction produced, the bicarbonate alkalinity concentration of the IWS and the presence or absence of residual lime must be taken into account. If low quantities of residual lime are present and the alkalinity is at or below the 120 $\mathrm{mg} \mathrm{CaCO}_{3} /$ liter recommended by Bunt (1988), then the amount of $\mathrm{NH}_{4}^{+}-\mathrm{N}$ in the WSF must be decreased below $25 \%$ to prevent medium $\mathrm{pH}$ from falling below recommended acceptable levels.

$E C$. With all treatments, there was a rapid decrease in root-zone $\mathrm{EC}$ as well as the concentration of all macronutrients tested (N, P, $\mathrm{K}, \mathrm{Ca}, \mathrm{Mg}, \mathrm{S}$ ) between planting (average $\mathrm{EC}=2.5 \mathrm{dS} \cdot \mathrm{m}^{-1}$ ) and week 1 (average $\mathrm{EC}=0.9 \mathrm{dS} \cdot \mathrm{m}^{-1}$ ) (Fig. 2), with a corresponding increase in the nutrient concentration measured in the top $2.5 \mathrm{~cm}$ of root medium within the pot (average $\mathrm{EC}=4.7 \mathrm{dS} \cdot \mathrm{m}^{-1}$ ) $($ data not shown). These data indicate that the initial nutrient concentration represents a highly soluble fraction and is not representative of the

Table 3. Parameters of nonlinear regression analysis from fitting Eqs. [1], [2], and [3] (see text) to percent P in tissue, based on root-medium $\mathrm{pH}$ at 8, 12, and 17 weeks after planting. I and S are the intercept and slope for Eqs. [2] and [3], respectively. The number of observations per sampling date was 48 at week 4 and 96 thereafter. Data from the lime treatments were used in the same analysis and are presented in Fig. 3. The analysis of the week 4 data was not included because of nonsignificance.

\begin{tabular}{lcccc}
\hline \hline $\begin{array}{l}\text { Estimated } \\
\text { parameters }\end{array}$ & Week 8 & Week 12 & Week 17 & Units \\
\hline Intercept $\left(\mathrm{I}_{1}\right)$ & $1.31 \pm 0.10^{\mathrm{z}}$ & $1.25 \pm 0.11$ & $1.21 \pm 0.14$ & Dry mass $(\%)$ \\
Slope $\left(\mathrm{S}_{1}\right)$ & $-0.08 \pm 0.02$ & $-0.06 \pm 0.2$ & $-0.07 \pm 0.02$ & Dry mass $(\%) / 1 \mathrm{pH}$ unit \\
Intercept $\left(\mathrm{I}_{2}\right)$ & $3.61 \pm 0.74$ & $5.13 \pm 1.19$ & $4.58 \pm 0.88$ & Dry mass $(\%)$ \\
Slope $\left(\mathrm{S}_{2}\right)$ & $-0.38 \pm 0.09$ & $-0.65 \pm 0.14$ & $-0.52 \pm 0.11$ & Dry mass $(\%) / 1 \mathrm{pH}$ unit \\
Calculated parameters & 7.5 & & & $\mathrm{pH}$ \\
$\quad \mathrm{X}_{\text {intersection }}$ & & 7.7 & \\
\hline${ }^{\mathrm{z}}$ Ninety-five percent confidence intervals were calculated as the parameter standard error $* \mathrm{t}_{0.025, \mathrm{n}}$ distribution.
\end{tabular}




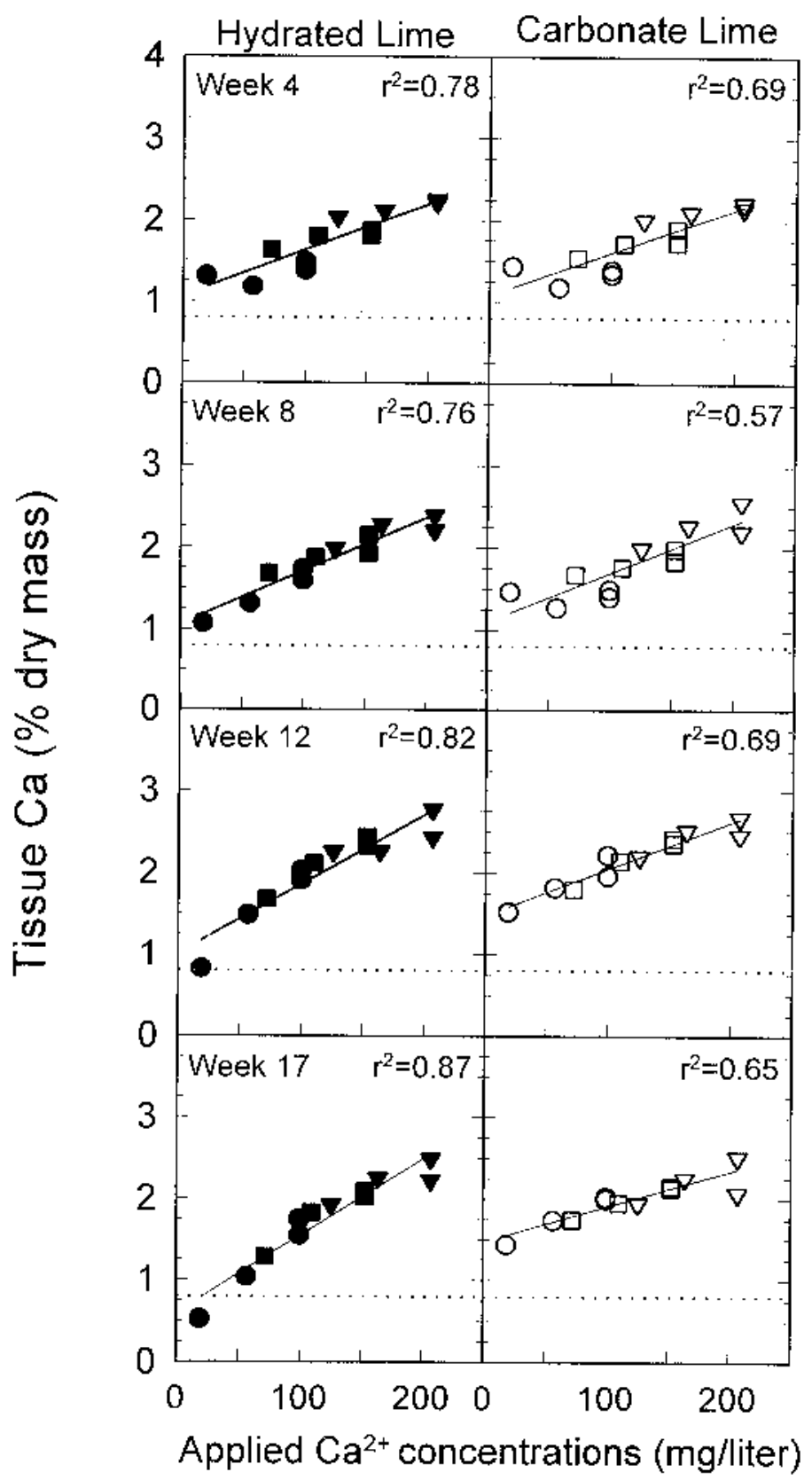

Fig. 4. The effect of applied $\mathrm{Ca}^{2+}$ concentration on the tissue $\mathrm{Ca}$ of impatiens at 4 , 8,12 , and 17 weeks after planting. Individual treatments are acidic water-soluble fertilizer (WSF) ( and O), neutral WSF ( $\square$ and $\square$ ), and basic WSF ( $\nabla$ and $\nabla$ ). The solid line (__ represents the predicted tissue Ca concentration based on linear regression analysis and the dotted line (...) represents the minimum recommended tissue Ca concentration. $R^{2}$ values were calculated as $1-\mathrm{SS}_{\text {residual }} /$ $\mathrm{SS}_{\text {corrected total }}$, and remaining statistical analyses of the individual parameters are presented in Table 4. Data are means of four samples at each date. long-term nutrient buffering capacity of the root medium, conclusions similar to those of Argo and Biernbaum (1996) with blended PNC materials in short-term (14-day) experiments.

The stratification of fertilizer salts may be caused by evaporation from the root-medium surface (Argo and Biernbaum, 1994, $1995,1996)$ or a water front moving into the root medium with each irrigation (Yelanich, 1995). After week 4, the root-zone EC increased for the remainder of the experiment (Fig. 2, Table 2). By the end of the experiment, the EC of the top $2.5 \mathrm{~cm}$ of root medium ranged from 30 to $40 \mathrm{dS} \cdot \mathrm{m}^{-1}$ compared to 1 to $2.5 \mathrm{dS} \cdot \mathrm{m}^{-1}$ for the remaining root medium within the same pot as measured with the SME.

EC is a measure of the total salt concentration in the root medium (Warncke and Krauskopf, 1983). The effect of the treatments on root-zone EC was based on a combination of the IWS and WSF EC. For example, with the acidified water, root-zone EC ranged from 1.8 to $2.4 \mathrm{dS} \cdot \mathrm{m}^{-1}$ with the different types of WSFs. The root-zone $\mathrm{EC}$ of the $\mathrm{RO}$ water treatments averaged $0.5 \mathrm{dS} \cdot \mathrm{m}^{-1}$ lower than that of the acidified water treatments from week 8 until the end of the experiment. When comparing WSF across IWS, the basic fertilizer/acidified water treatment had a root-zone EC 1.3 $\mathrm{dS} \cdot \mathrm{m}^{-1}$ higher than the acidic fertilizer/RO water by the end of the experiment. It is important to note that the concentration of $\mathrm{N}$ and $\mathrm{K}$ in the applied nutrient solutions were similar for all treatments and the range of treatments affected root-medium K minimally, and tissue $\mathrm{N}$ and $\mathrm{K}$ concentrations were in the acceptable plantgrowth range recommended by Fortney and Wolf (1981) (data not shown). In order to fine tune general guidelines for $\mathrm{N}$ and $\mathrm{K}$ nutrition in container media based on EC, the EC of the nutrient solution must be considered.

Phosphorus. The constant application of $20 \mathrm{mg} \mathrm{PO}_{4}-\mathrm{P} / \mathrm{liter}$ resulted in water-soluble $\mathrm{PO}_{4}-\mathrm{P}$ medium concentrations ranging from 3 to $25 \mathrm{mg} \mathrm{PO}_{4}-\mathrm{P} /$ liter by the end of the experiment (Fig. 2). In general, the higher the root-medium $\mathrm{pH}$, the lower the rootmedium $\mathrm{PO}_{4}-\mathrm{P} / \mathrm{m}^{3}$.

In mineral soils fertilized with $\mathrm{P}$, calcium phosphates (dicalcium phosphate and dicalcium phosphate dihydrate) initially control $\mathrm{PO}_{4}-\mathrm{P}$ solubility at high $\mathrm{pH}(>7.0)$ and $\mathrm{Al}$ and $\mathrm{Fe}$ phosphates control $\mathrm{PO}_{4}-\mathrm{P}$ solubility at low $\mathrm{pH}$ (Lindsay and Moreno, 1960). In acidic organic soils and soilless root media, which tend to contain naturally low amounts of $\mathrm{Al}$ and $\mathrm{Fe}, \mathrm{P}$ does not precipitate at low pH but does at high pH (Lucas and Davis, 1961; Peterson, 1981; Yeager and Barrett, 1985). Thus, the reduction in the concentration of water-soluble $\mathrm{PO}_{4}-\mathrm{P}$ at the higher $\mathrm{pH}$ range probably was due, at least initially, to precipitation of $\mathrm{P}$ as dicalcium phosphate or dicalcium phosphate dihydrate.

Lucas and Davis (1961) and Peterson (1981) concluded that the optimal $\mathrm{pH}$ for $\mathrm{PO}_{4}-\mathrm{P}$ nutrition was 5.5 in media without soil, because above this $\mathrm{pH}$, water-soluble $\mathrm{PO}_{4}-\mathrm{P}$ concentrations began to decrease. In comparison, Adams et al. (1978) found that the $\mathrm{P}$ content of lettuce leaves was unaffected by medium $\mathrm{pH}$ up to 6.5 ,

Table 4. Parameters of linear regression analysis for tissue $\mathrm{Ca}$, based on the applied concentration of $\mathrm{Ca}^{2+}$ in the nutrient solution. The number of observations per lime treatment was 24 at week 4 and 48 thereafter. Data are presented in Fig. 4.

\begin{tabular}{|c|c|c|c|c|c|}
\hline & Week 4 & Week 8 & Week 12 & Week 17 & Units \\
\hline \multicolumn{6}{|c|}{ Hydrated lime } \\
\hline Intercept & $1.06 \pm 0.18^{\mathrm{z}}$ & $1.06 \pm 0.14$ & $1.01 \pm 0.16$ & $0.59 \pm 0.15$ & Dry mass $(\%)$ \\
\hline Slope & $0.006 \pm 0.001$ & $0.006 \pm 0.001$ & $0.008 \pm 0.001$ & $0.009 \pm 0.001$ & Dry mass $(\%) / \mathrm{mg} \cdot$ liter $^{-1}$ \\
\hline \multicolumn{6}{|c|}{ Carbonate lime } \\
\hline Intercept & $1.08 \pm 0.25$ & $1.10 \pm 0.20$ & $1.48 \pm 0.15$ & $1.47 \pm 0.13$ & Dry mass $(\%)$ \\
\hline Slope & $0.005 \pm 0.001$ & $0.006 \pm 0.001$ & $0.006 \pm 0.001$ & $0.004 \pm 0.001$ & Dry mass $(\%) / \mathrm{mg} \cdot \operatorname{liter}^{-1}$ \\
\hline
\end{tabular}




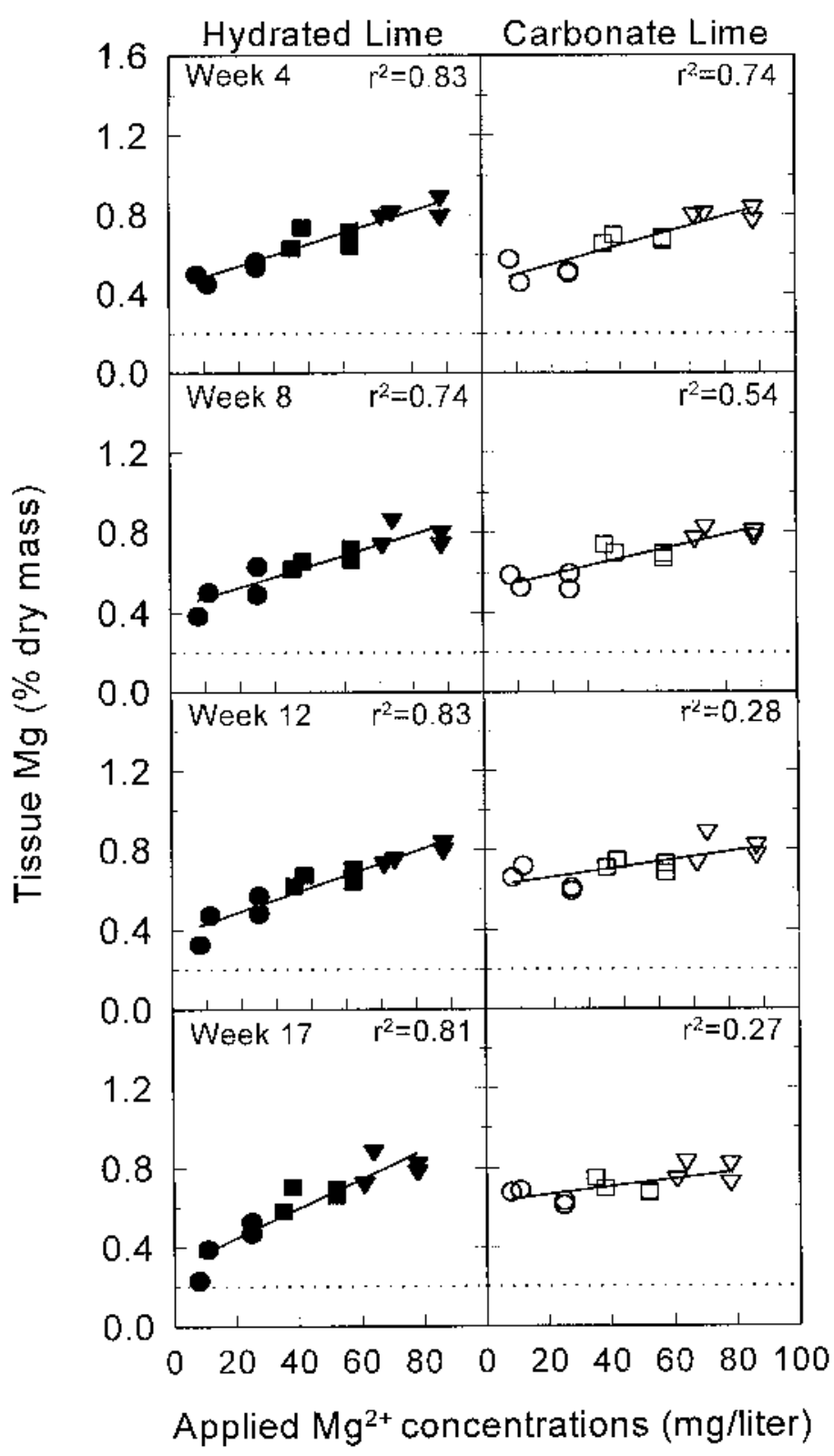

Fig. 5. The effect of applied $\mathrm{Mg}^{2+}$ concentration on the tissue $\mathrm{Mg}$ of impatiens at 4, 8,12 , and 17 weeks after planting. Individual treatments are acidic water-soluble fertilizer (WSF) ( and $\bigcirc$ ), neutral WSF ( $\boldsymbol{\square}$ and $\square$ ), and basic WSF $(\boldsymbol{\nabla}$ and $\nabla)$. The solid line (-) represents the predicted tissue $\mathrm{Mg}$ concentration based on linear regression analysis and the dotted line (....) represents the minimum recommended tissue $\mathrm{Mg}$ concentration. $R^{2}$ values were calculated as 1-SS $\mathrm{Sesidual} / \mathrm{SS}_{\text {corrected total }}$, and remaining statistical analyses of the individual parameters are presented in Table 5. Data are means of four samples at each date. even though the concentration of water-soluble $\mathrm{PO}_{4}-\mathrm{P}$ measured in the medium was $38 \%$ of that measured at $\mathrm{pH}$ 5.5. In this experiment, when root-medium $\mathrm{pH}$ was plotted against tissue $\mathrm{P}$ concentration, a maximum critical root-medium $\mathrm{pH}$ for $\mathrm{PO}_{4}-\mathrm{P}$ nutrition was 7.5, 7.7, and 7.4 at weeks 8, 12, and 17, respectively (Fig. 3, Table 3). Below this root-medium $\mathrm{pH}$, tissue $\mathrm{P}$ increased at $0.06 \%$ to $0.08 \%$ of the total dry mass per $1 \mathrm{pH}$ unit decrease, and above the critical $\mathrm{pH}$, tissue $\mathrm{P}$ decreased at $0.38 \%$ to $0.65 \%$ of the total dry mass per $1 \mathrm{pH}$ unit increase (Table 3 ).

The form of water-soluble $\mathrm{PO}_{4}-\mathrm{P}$ is important for uptake into the roots and depends on the root-medium $\mathrm{pH}$. In the root-medium $\mathrm{pH}$ range of this experiment (4.5 to 8.5), the two forms present are $\mathrm{H}_{2} \mathrm{PO}_{4}^{-}$and $\mathrm{HPO}_{4}^{2-}$ with an equilibrium constant of 7.2. The $\mathrm{H}_{2} \mathrm{PO}_{4}^{-}$form of water-soluble $\mathrm{P}$ is 10 times more available to the plant than the $\mathrm{HPO}_{4}{ }^{2-}$ form (Bunt, 1988). At a medium $\mathrm{pH}>7.2$, a majority of the water-soluble $\mathrm{P}$ is in the less-available $\mathrm{HPO}_{4}{ }^{2-}$ form that resulted in the larger reduction in tissue $\mathrm{P}$ than at a medium $\mathrm{pH}$ $<7.2$, at which a majority of the measured $\mathrm{P}$ is in the more-available $\mathrm{H}_{2} \mathrm{PO}_{4}^{-}$form. Thus, while the concentration of water-soluble $\mathrm{PO}_{4}^{-}$ $\mathrm{P}$ in the root medium decreased with increasing $\mathrm{pH}$, the effect on tissue $\mathrm{P}$ was minimal until the form of the water-soluble $\mathrm{PO}_{4}-\mathrm{P}$ changed to a less-available form.

Calcium. After week 1, root-medium $\mathrm{Ca}^{2+}$ concentrations increased for the remainder of the experiment, but the increase depended on all three factors tested (Fig. 2, Table 2). In general, the higher the concentration of $\mathrm{Ca}^{2+}$ in the nutrient solution, the higher the water-soluble $\mathrm{Ca}^{2+}$ concentration in the root medium over the remaining 16 weeks of the experiment. The presence of the carbonate lime also increased water-soluble $\mathrm{Ca}^{2+}$ compared to that of the hydrated lime treatments, but the average difference was small (20 $\mathrm{mg} \mathrm{Ca}^{2+} /$ liter) and probably was due to the reaction of the acidic or neutral WSF with residual carbonate lime in the medium.

There was a poor relationship between water-soluble $\mathrm{Ca}^{2+}$ concentrations in the root medium and tissue $\mathrm{Ca}$ (data not shown). The root-medium $\mathrm{Ca}^{2+}$ concentrations measured at weeks 4, 8, 12, and 17 are the maximum concentrations from the previous 4 -week period and therefore do not represent the average conditions from which plant growth and $\mathrm{Ca}$ uptake occurred. In comparison, the range of $\mathrm{Ca}^{2+}$ concentrations in the various nutrient solutions produced from the factorial combinations of IWS and WSF remained constant over time, and there was a relationship between the applied $\mathrm{Ca}^{2+}$ concentration in the nutrient solution and tissue Ca.

With both lime types, there was a linear increase in tissue $\mathrm{Ca}$ as the applied concentrations increased from 18 to $210 \mathrm{mg} \mathrm{Ca}^{2+} /$ liter with the IWS and WSF combinations (Fig. 4, Table 4). The intercept value reflects the $\mathrm{Ca}^{2+}$ buffering capacity of the medium if no $\mathrm{Ca}^{2+}$ were applied in the fertilizer solution. The relationship was similar for both lime types up to week $8(0.2 \%$ increase in tissue $\mathrm{Ca}$ per $40 \mathrm{mg} \cdot$ liter $^{-1}$ increase in applied $\mathrm{Ca}^{2+}$ concentration,

Table 5. Parameters of linear regression analysis for tissue $\mathrm{Mg}$, based on the applied concentration of $\mathrm{Mg}^{2+}$ in the nutrient solution. The number of observations per lime treatment was 24 at week 4 and 48 thereafter. Data are presented in Fig. 5.

\begin{tabular}{lccccc}
\hline \hline \multicolumn{7}{c}{ Week 4} & Week 8 & Week 12 & Week 17 & Units \\
\hline Intercept & $0.43 \pm 0.05^{\mathrm{z}}$ & $0.42 \pm 0.05$ & $0.37 \pm 0.04$ & $0.30 \pm 0.05$ & Dry mass $(\%)$ \\
Slope & $0.005 \pm 0.001$ & $0.005 \pm 0.001$ & $0.006 \pm 0.001$ & $0.007 \pm 0.001$ & Dry mass $(\%) / \mathrm{mg}^{-l i t e r}{ }^{-1}$ \\
\multicolumn{5}{c}{ Carbonate lime } \\
Intercept & $0.45 \pm 0.06$ & $0.51 \pm 0.05$ & $0.61 \pm 0.06$ & $0.62 \pm 0.05$ & Dry mass $(\%)$ \\
Slope & $0.005 \pm 0.001$ & $0.004 \pm 0.001$ & $0.002 \pm 0.001$ & $0.002 \pm 0.001$ & Dry mass $(\%) / \mathrm{mg}^{-l i t e r}{ }^{-1}$ \\
\hline
\end{tabular}

${ }^{\mathrm{z} N i n e t y-f i v e ~ p e r c e n t ~ c o n f i d e n c e ~ i n t e r v a l s ~ w e r e ~ c a l c u l a t e d ~ a s ~ t h e ~ p a r a m e t e r ~ s t a n d a r d ~ e r r o r ~}{ }^{*} \mathrm{t}_{0.025, \mathrm{n}}$ distribution. 


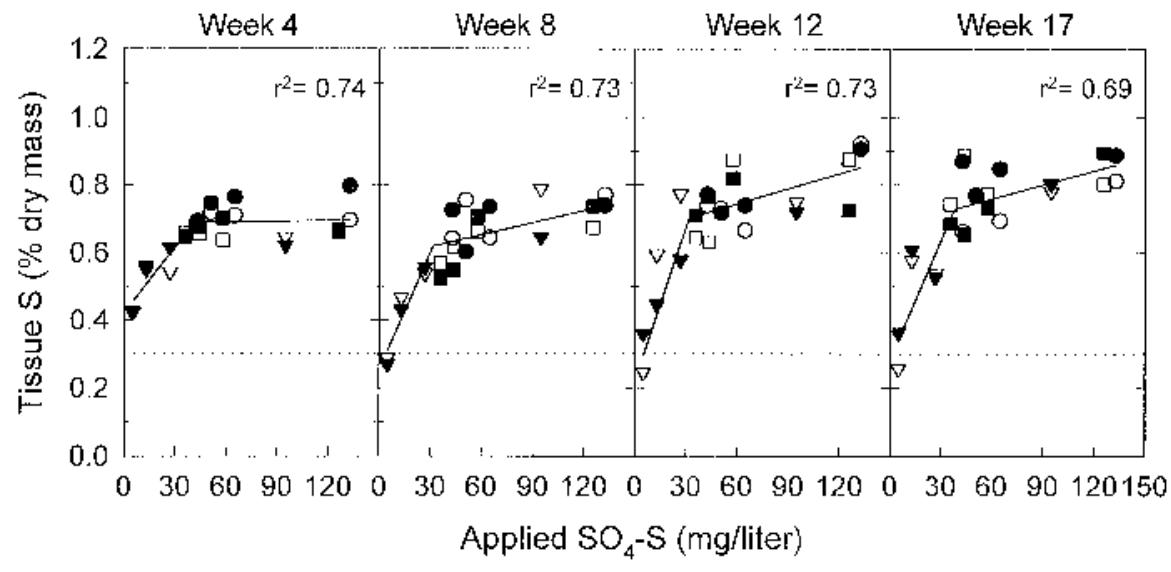

Fig. 6. The effect of applied $\mathrm{SO}_{4}-\mathrm{S}$ concentration on the tissue $\mathrm{S}$ of impatiens at 4, 8, 12, and 17 weeks after planting. Filled symbols are hydrated lime treatments and hollow symbols are carbonate lime treatments with acidic water-soluble fertilizer (WSF) $(\mathcal{O}$ and $\bigcirc)$, neutral WSF ( $\square$ and $\square$ ), and basic WSF ( $\nabla$ and $\nabla$ ). The solid line $(-)$ represents the predicted tissue $S$ concentration based on Eq. [1] and the dotted line (....) represents the minimum recommended tissue $S$ concentration. $R^{2}$ values were calculated as 1-SS $\mathrm{SS}_{\text {residual }} / \mathrm{SS}_{\text {corrected total }}$, and remaining statistical analyses of the individual parameters are presented in Table 6. Data are means of four samples at each date.

tional buffering capacity of the residual carbonate lime.

Magnesium. As with $\mathrm{Ca}^{2+}$, root-medium $\mathrm{Mg}^{2+}$ concentrations increased from week 1 to the end of the experiment, and the increase depended on all three factors tested (Fig. 2,

with a minimum tissue concentration of $1.0 \%$ to $1.1 \%$ ), after which tissue $\mathrm{Ca}$ decreased faster with the hydrated lime and low-solution $\mathrm{Ca}^{2+}$ compared to that of the carbonate lime treatments. The reduction in the intercept of the hydrated lime treatments by weeks 12 and 17 indicates a reduction in the $\mathrm{Ca}^{2+}$ buffering capacity of the medium compared to that of the carbonate lime treatments. Using Eq. [1], similar tissue Ca concentrations could be obtained, independent of the lime type, with the addition of $>180 \mathrm{mg} \mathrm{Ca}^{2+} /$ liter in the nutrient solution throughout the experiment. In addition, these results indicate that the ionic composition and $\mathrm{N}$ form of the WSF had little effect on Ca uptake. Instead, the main factor controlling Ca uptake above the minimum buffering capacity of the medium was bulk nutrient solution $\mathrm{Ca}^{2+}$ concentration as influenced by the IWS and WSF.

One possibility for the larger reduction in tissue $\mathrm{Ca}$ with the hydrated lime treatments compared to that of the carbonate lime treatments was that $\mathrm{Ca}^{2+}$ availability was reduced at low $\mathrm{pH}$, as indicated by Peterson (1981). Plants grown in media containing the hydrated lime and irrigated with RO water containing either acidic or neutral WSF had a similar root-medium $\mathrm{pH}$ throughout the experiment (Fig. 2), but the total applied $\mathrm{Ca}^{2+}$ concentration was higher with the neutral WSF (70 $\mathrm{mg} \mathrm{Ca}^{2+} /$ liter) than the acidic WSF (18 $\mathrm{mg} \mathrm{Ca}^{2+} /$ liter). The tissue Ca concentration was also higher with the RO-neutral WSF treatment at each of the four sampling date $(1.6 \%, 1.7 \%, 1.7 \%$, and $1.3 \%$, respectively) than with the RO-acidic WSF $(1.3 \%, 1.1 \%, 0.8 \%$, and $0.5 \%$, respectively) (Fig. 4). Thus, low pH did not, in itself, reduce $\mathrm{Ca}^{2+}$ uptake but did reflect a lack of residual lime in the medium. The difference in tissue $\mathrm{Ca}$ concentrations between the hydrated $(1.3 \% \mathrm{Ca})$ and carbonate $(1.7 \% \mathrm{Ca})$ lime treatments in plants receiving $\mathrm{RO}$ water/ neutral fertilizer at the week 17 sampling date reflects the addi-
Table 2). In general, the higher the concentration of $\mathrm{Mg}^{2+}$ in the nutrient solution, the higher the water-soluble $\mathrm{Mg}^{2+}$ concentration in the root medium over the remaining 16 weeks of the experiment. The presence of the carbonate lime increased water-soluble $\mathrm{Mg}^{2+}$ compared to that of the hydrated lime treatments, but the difference was small ( $15 \mathrm{mg} \mathrm{Mg}^{2+} /$ liter), and probably was due to the reaction of the acidic fertilizer with the carbonate lime.

With both lime types, there was a linear increase in tissue $\mathrm{Mg}$ as the applied concentrations increased from 5 to $80 \mathrm{mg} \mathrm{Mg}^{2+} / \mathrm{liter}$ with the various nutrient solutions (Fig. 5, Table 5). The intercept value reflects the $\mathrm{Mg}^{2+}$ buffering capacity of the medium if no $\mathrm{Mg}^{2+}$ were applied in the fertilizer solution. The relationship was similar for both lime types up to week 8, after which tissue Mg decreased with the hydrated lime and low-solution $\mathrm{Mg}^{2+}$, while with the carbonate lime treatments, there was little decrease in tissue $\mathrm{Mg}$ with decreasing concentrations of applied $\mathrm{Mg}^{2+}(0.05 \%$ increase in tissue $\mathrm{Mg}$ per $25 \mathrm{mg} \cdot \mathrm{liter}^{-1}$ increase in applied $\mathrm{Mg}^{2+}$ concentration). From Eq. [1], similar tissue Mg concentrations were obtained, independent of the lime type, with the addition of $>60 \mathrm{mg}$ $\mathrm{Mg}^{2+} /$ liter in the nutrient solution for the duration of the experiment. These results indicate that the ionic composition and $\mathrm{N}$ form of the WSF had minimal effect on Mg uptake. The main factor controlling $\mathrm{Mg}$ uptake above the minimum buffering capacity of the medium was bulk nutrient solution $\mathrm{Mg}^{2+}$ concentration, as influenced by the IWS and WSF.

Sulfate. IWS and WSF were the main factors affecting rootmedium $\mathrm{SO}_{4}-\mathrm{S}$ concentrations (Fig. 2, Table 2). In general, the higher the concentration in the applied nutrient solution, the higher the concentration of $\mathrm{SO}_{4}-\mathrm{S}$ in the root medium at the end of the experiment. When low concentrations of $\mathrm{SO}_{4}-\mathrm{S}$ were applied ( $\mathrm{RO}$ water/basic fertilizer), low concentrations were measured in the

Table 6. Parameters of nonlinear regression analysis from fitting Eqs. [1], [2], and [3] (see text) to percent $\mathrm{S}$ in tissue, based on the concentration of $\mathrm{SO}_{4}-\mathrm{S}$ in the nutrient solution at $4,8,12$, and 17 weeks after planting. The number of observations per sampling date was 48 at week 4 and 96 thereafter. Data from the lime treatments were used in the same analysis and are presented in Fig. 6.

\begin{tabular}{|c|c|c|c|c|c|}
\hline $\begin{array}{l}\text { Estimated } \\
\text { parameters }\end{array}$ & Week 4 & Week 8 & Week 12 & Week 17 & Units \\
\hline Intercept $\left(\mathrm{I}_{1}\right)$ & $0.42 \pm 0.11^{z}$ & $0.25 \pm 0.06$ & $0.22 \pm 0.08$ & $0.28 \pm 0.07$ & Dry mass $(\%)$ \\
\hline Slope $\left(\mathrm{S}_{1}\right)$ & $0.006 \pm 0.002$ & $0.012 \pm 0.003$ & $0.015 \pm 0.004$ & $0.012 \pm 0.003$ & Dry mass $(\%) / \mathrm{mg} \cdot$ liter $^{-1}$ \\
\hline Intercept $\left(\mathrm{I}_{2}\right)$ & $0.69 \pm 0.04$ & $0.58 \pm 0.05$ & $0.66 \pm 0.05$ & $0.68 \pm 0.06$ & Dry mass $(\%)$ \\
\hline Slope $\left(\mathrm{S}_{2}\right)$ & $0.000 \pm 0.001$ & $0.002 \pm 0.001$ & $0.002 \pm 0.001$ & $0.001 \pm 0.001$ & Dry mass $(\%) / \mathrm{mg} \cdot$ liter $^{-1}$ \\
\hline \multicolumn{6}{|c|}{ Calculated parameters } \\
\hline $\mathrm{X}_{\text {intersection }}$ & 41 & 32 & 32 & 38 & $\mathrm{mg} \cdot$ liter $^{-1}$ \\
\hline
\end{tabular}


root medium, indicating that gypsum and $\mathrm{MgSO}_{4}$ initially incorporated with the PNC had minimal persistence in the root zone. However, with the lowest applied $\mathrm{SO}_{4}-\mathrm{S}$ concentration $\left(3 \mathrm{mg} \mathrm{SO}_{4}^{-}\right.$ $\mathrm{S} /$ liter), root-zone $\mathrm{SO}_{4}-\mathrm{S}$ concentrations were maintained at $15 \mathrm{mg}$ $\mathrm{SO}_{4}-\mathrm{S} /$ liter and may represent the base buffering capacity of the root medium, residual gypsum, or movement of $\mathrm{SO}_{4}-\mathrm{S}$ back into the root zone from high concentration at the root-medium surface.

There was a minimal increase in tissue $S$ with increasing concentration of applied $\mathrm{SO}_{4}-\mathrm{S}$ above 30 to $40 \mathrm{mg}$ S/liter (Fig. 6, Table 6). Above this concentration, tissue $\mathrm{S}$ increased at $0.0 \%$ to $0.05 \%$ of dry mass per $30 \mathrm{mg} \cdot$ liter $^{-1}$ increase in the applied $\mathrm{SO}_{4}-\mathrm{S}$ concentration. Below this minimum critical concentration, tissue $\mathrm{S}$ decreased at $0.2 \%$ to $0.5 \%$ of dry mass per $30 \mathrm{mg} \cdot$ liter $^{-1}$ decrease in the applied $\mathrm{SO}_{4}-\mathrm{S}$ concentration. This minimum critical concentration of 30 to $40 \mathrm{mg}$ S/liter corresponds to the $30 \mathrm{mg}$ S/liter recommended by Reddy et al. (1994) for container plant production. In addition, the larger reduction in tissue $S$ at the week 4 analysis (below $40 \mathrm{mg}$ S/liter in the applied solution) adds further evidence that a large percentage of the gypsum or $\mathrm{MgSO}_{4}$ did not persist in the root zone, as suggested in this experiment and by Argo and Biernbaum (1996) and root-medium $\mathrm{Ca}^{2+}$ and tissue concentrations. Reddy et al. (1994) found that $11 \%$ of the IWS tested, based on a survey of water samples, contained $>30 \mathrm{mg} \mathrm{S} /$ liter. Since many blended WSF do not contain $\mathrm{SO}_{4}-\mathrm{S}$ (Peter's Fertilizers, 1981), additional $\mathrm{SO}_{4}-\mathrm{S}$ may need to be added as a water-soluble source, as suggested by Reddy and Madore (1995).

Root-medium $\mathrm{SO}_{4}-\mathrm{S}$ concentrations up to $150 \mathrm{mg} \mathrm{S} / \mathrm{liter}$ and applied concentration up to $130 \mathrm{mg}$ S/liter did not cause a significant decrease in tissue $\mathrm{Ca}$ concentrations (plant tissue $\mathrm{Ca}$ average with acidified water $=1.9 \%, 2.0 \%, 2.4 \%$, and $2.1 \%$; and with well water $=1.8 \%, 1.9 \%, 2.3 \%$, and $2.0 \%$ at weeks $4,8,12$, and 17 , respectively). Although $\mathrm{Ca}^{2+}$ and $\mathrm{SO}_{4}-\mathrm{S}$ will form soluble ion complexes in solution (Lindsay, 1979), which may reduce plant availability, under the conditions of the experiment, enough of the water-soluble $\mathrm{Ca}^{2+}$ remained in the root medium in the free ion form to not inhibit plant uptake.

Root-medium buffering capacity. The $\mathrm{pH}$ and nutrient buffering capacity of peat often are associated with the cation exchange capacity (CEC) that is due to the $\mathrm{pH}$-dependent exchange of cations with $\mathrm{H}^{+}$ions from organic acid functional groups on the peat particles (Helling et al., 1964). For example, at a pH of 3.7, 4.5, 5.5 , and 7.8 , acid sphagnum peat is $100 \%, 50 \%, 30 \%$, and $0 \% \mathrm{H}^{+}$ saturated, respectively (Lucas et al., 1975; Puustjarvi and Robertson, 1975). Thus, the actual buffering capacity over the $\mathrm{pH}$ range in this experiment probably represents a fraction of the total CEC.

This experiment demonstrated that a large difference in $\mathrm{pH}$ and nutrient buffering capacity could be obtained with the same root medium by using two liming materials with different reaction rates and amounts of unreacted material remaining in the medium at equilibrium. Perhaps differences in the $\mathrm{pH}$ and nutrient buffering capacity observed in commercial media may be attributed to differences in the type and amount of liming material used rather than CEC (C. Bethke, Michigan Peat, Houston, Texas, personal communications).

Macronutrient management. The primary macronutrients $(\mathrm{N}$, $\mathrm{P}, \mathrm{K})$ typically are contained in WSFs. Nitrogen and $\mathrm{K}$ can be managed based on the EC of the nutrient solution. If $\mathrm{PO}_{4}-\mathrm{P}$ is present in the WSF, it also can be managed acceptably via EC if the root-medium $\mathrm{pH}$ is $<7.3$ to 7.5 .

The secondary macronutrients $(\mathrm{Ca}, \mathrm{Mg}$, and $\mathrm{S}$ ) frequently are ignored because the carriers (lime, gypsum, and $\mathrm{MgSO}_{4}$ ) are incorporated in relatively large amounts with the PNC fertilizers and may buffer the root media for a long period (Bunt, 1988;
Nelson, 1991). Gypsum and $\mathrm{MgSO}_{4}$ do not persist in the root zone of subirrigated pots and probably can be removed by top-watering methods with leaching or mist propagation. Dolomitic carbonate lime buffered the root medium for $\mathrm{Ca}^{2+}$ and $\mathrm{Mg}^{2+}$, but long-term reliance on residual lime may be risky, because the amount of material present or its persistence in the medium cannot be determined with the SME analysis.

An alternative method for managing secondary macronutrients may be to ignore the material incorporated with the PNC and lime in the medium and apply nutrient-solution $\mathrm{Ca}^{2+}, \mathrm{Mg}^{2+}$, and $\mathrm{SO}_{4}-\mathrm{S}$ based on the sum of those ions from both the IWS and WSF, as suggested by Biernbaum (1992) and Vetanovetz and Knauss (1988). According to the results from this experiment, the concentrations of $\mathrm{Ca}^{2+}, \mathrm{Mg}^{2+}$, and $\mathrm{SO}_{4}-\mathrm{S}$ that should be applied in the nutrient solution on a constant basis are $160 \mathrm{mg} \mathrm{Ca}^{2+} / \mathrm{liter}, 50 \mathrm{mg}$ $\mathrm{Mg}^{2+} /$ liter, and $30 \mathrm{mg} \mathrm{SO}$-S/liter.

There are two main sources of $\mathrm{Mg}^{2+}$ for WSFs, $\mathrm{MgSO}_{4}$ and $\mathrm{Mg}\left(\mathrm{NO}_{3}\right)_{2}$. If $\mathrm{MgSO}_{4}$ is used for the $\mathrm{Mg}^{2+}$ source, adequate concentrations of $\mathrm{SO}_{4}-\mathrm{S}$ also will be applied. However, there is only one source of highly soluble $\mathrm{Ca}^{2+}$ typically used in WSF, $\mathrm{Ca}\left(\mathrm{NO}_{3}\right)_{2}$. Therefore, the recommendations for $\mathrm{Ca}^{2+}$ supplied by the nutrient solution also will have a direct effect on $\mathrm{NH}_{4}^{+}-\mathrm{N}$ content in the WSF and on root-medium $\mathrm{pH}$ management. This type of secondary macronutrient management should result in acceptable $\mathrm{Ca}^{2+}$ concentrations for plant uptake, a medium $\mathrm{pH}$ maintained at a level much closer to the recommended 5.8 to 6.4 range (Warncke and Krauskopf, 1983), and the conservation of any residual liming material.

Calcium and $\mathrm{PO}_{4}-\mathrm{P}$ can be mixed together in high concentrations, such as in a fertilizer stock tank, only if the $\mathrm{pH}<2.0(\mathrm{R}$. Vetanovetz, Scotts, personal communication), while $\mathrm{Ca}^{2+}$ and $\mathrm{SO}_{4}-\mathrm{S}$ cannot be combined in a stock tank without subsequent precipitation. Multiple injectors may be required for this type of secondary macronutrient management. Other options for applying $\mathrm{Ca}^{2+}$ include investigating the use of $\mathrm{CaCl}_{2}$ or chelated $\mathrm{Ca}$ if a high percentage of $\mathrm{NH}_{4}^{+}-\mathrm{N}$ and $\mathrm{Ca}^{2+}$ is desired in the WSF.

\section{Conclusion}

Impatiens are highly tolerant of a wide range of growth conditions. Because of the similarity in the shoot dry mass accumulation between treatments, the relationships that were developed between the applied nutrient concentration or medium $\mathrm{pH}$ and the tissue nutrient concentration were not confounded because of differences in plant growth. These relationships also may be valid for other species used in container-plant production. However, the minimum critical tissue-nutrient concentrations that causes a reduction in growth may be species dependent (Dole and Wilkins, 1988). If other species were grown under the same conditions as those found in this experiment, it is possible that a limitation in growth caused by a nutrient deficiency or toxicity would have occurred.

In the production of container-grown crops, it is no longer acceptable to manage the $\mathrm{pH}$ and macronutrient concentrations in the root medium and plant tissue with high WSF concentrations and high leaching rates (Biernbaum, 1992). Irrigation systems that minimize or eliminate water and fertilizer runoff into the environment currently exist. Optimizing the $\mathrm{pH}$ and nutrient management of low- or nonleaching irrigation systems requires an understanding of how factors such as lime, IWS, and WSF interact during production. Additional research is needed to determine if recommendations for $\mathrm{pH}$ and macronutrient management must be refined further to include differences in root media and or plant species. 


\section{Literature Cited}

Adams, P., C.J. Graves, and G.W. Winsor. 1978. Some responses of lettuce, grown in beds of peat, to nitrogen, potassium, magnesium, and molybdenum. J. Hort. Sci. 53:275-281.

Anderson, R.L. and L.A. Nelson. 1975. A family of models involving intersecting straight lines and concomitant experimental designs useful in evaluating response to fertilizer nutrients. Biometrics 31:303-318.

Argo, W.R. and J.A. Biernbaum. 1994. Irrigation requirements, rootmedium $\mathrm{pH}$, and nutrient concentrations of Easter lilies grown in five peat-based media with and without an evaporation barrier. J. Amer. Soc. Hort. Sci. 119:1151-1156.

Argo, W.R. and J.A. Biernbaum. 1995. Root-medium nutrient levels and irrigation requirements of poinsettias grown in five root media. HortScience 30:535-538.

Argo, W.R. and J.A. Biernbaum. 1996. Availability and persistence of macronutrients from lime and preplant nutrient charge fertilizers in peatbased root media. J. Amer. Soc. Hort. Sci. (In press.)

Barker, A.V. and H.A. Mills. 1980. Ammonium and nitrate nutrition of horticultural crops. Hort. Rev. 2:395-423.

Biernbaum, J.A. 1992. Root-zone management of greenhouse containergrown crops to control water and fertilizer use. HortTechnology 2:127132.

Bloxham, A. 1990. Orthophosphate in surface waters. QuikChem method no. 10-115-01-1-O. Lachat Instruments, Milwaukee, Wis.

Bunt, A.C. 1988. Media and mixes for container-grown plants. Unwin Hyman, London.

Chapin, J.K. 1980. The effect of fineness in limestone on the $\mathrm{pH}$ of 50:50 peat-vermiculite mix. Benchmarks 1(7):7.

Chau, A.S.Y. 1984. Water and salt, p. 617-638. In: S. Williams (ed.). Official methods of analysis of the association of official analytical chemists. Assn. of Official Anal. Chemists, Arlington, Virginia.

Diamond, D. 1986a. Nitrate + nitrite in soil extracts. QuikChem method no. 12-107-04-1-B. Lachat Instruments, Milwaukee, Wis.

Diamond, D. 1986b. Ammonia in soil extracts. QuikChem method no. 12107-06-2-A. Lachat Instruments, Milwaukee, Wis.

Dole, J.M. and H.F. Wilkins. 1988. Tissue testing of selected floricultural pot crops. Minnesota State Flo. Bul. 37(5):13-15.

Fisher, P.R. 1995. Prediction and control of stem elongation and flowering in poinsettia and Easter lily. PhD diss., Michigan State Univ., East Lansing.

Fortney, W.R. and T.K. Wolf. 1981. Determining nutritional status: Plant analysis. Pennsylvania Flower Grower's Bul. 331, 1:5-11.

Gibaly, H.E. and J.H. Axley. 1955. A chemical method for the rating of agricultural limestones used as soil amendments. Soil Sci. Soc. Amer. Proc. 20:301-302.

Hawkes, G.R., D.B. Campbell, A.E. Ludwick, R.M. Millaway, and R.M. Thorup (eds.). 1985. Fertilizers: A source of plant nutrients, p. 83-110. In: Western fertilizer handbook. 7th ed. Interstate, Danville, Ill.

Helling, C.S., G. Chesters, and R.B. Corey. 1964. Contribution of organic matter and clay to soil cation-exchange capacity as affected by the $\mathrm{pH}$ of the saturating solution. Soil Sci. Soc. Amer. Proc. 28:517-520.

Lindsay, W.L. 1979. Chemical equilibria in soils. Wiley, New York.

Lindsay, W.L. and E.C. Moreno. 1960. Phosphate phase equilibria in soils. Soil Sci. Soc. Amer. Proc. 24:177-182.

Lucas, R.E. and J.F. Davis. 1961. Relationships between pH values of organic soils and availabilities of 12 plant nutrients. Soil Sci. 92:171-182.

Lucas, R.E., P.E. Rieke, J.C. Shickluna, and A. Cole. 1975. Lime and fertilizer requirements for peats, p. 51-70. In: D.W. Robinson and J.G.D. Lamb (eds.). Peat in horticulture. Academic Press, London.

Ludwig, L.S. and J.C. Peterson. 1984. An assessment of the chemical properties of water from floriculture industry firms throughout Ohio and the United States. HortScience 19:521. (Abstr.)

Marschner, H. 1986. Mineral nutrition of higher plants. Academic Press, London.

McKnight, R. 1991. Sulfate: Turbidimetric method with soil extracts. QuikChem method no. 12-116-10-1-C. Lachat Instruments, Milwaukee, Wis.

Nelson, P.V. 1991. Greenhouse operations and management. 4th ed. Prentice Hall, Englewood Cliffs, N.J.

Parfitt, R.L. and B.G. Ellis. 1966. Studies on Michigan agricultural limestones. Michigan Agr. Expt. Sta. Quarterly Bul. 49(2):12-23.

Peter's Fertilizers. 1981. Fertilizer sales manual. Scotts, Marysville, Ohio. Peterson, J.C. 1981. Modify your pH perspective. Florist's Rev. 169(4386):34-35, 92-93.

Puustjarvi, V. and R.A. Robertson. 1975. Physical and chemical properties, p. 23-38. In: D.W. Robinson and J.G.D. Lamb (eds.). Peat in horticulture. Academic Press, London.

Reddy, S.K. and M.A. Madore. 1995. Is there enough sulfur in your water? GrowerTalks 58(8):92.

Reddy, S.K., M.A. Madore, and P.A. King. 1994. Survey of sulfur levels in greenhouse irrigation waters. HortScience 29:503. (Abstr.)

Schollenberger, C.J. and R.M. Salter. 1943. A chart for evaluating agricultural limestone. J. Amer. Soc. Agron. 35:955-966.

Sheldrake, R. 1980. Lime source and quantity study on peat-vermiculite1980. Benchmarks 1(7):6-7.

Spurway, C.H. and C.E. Wildon. 1938. Water conditioning for greenhouses. Michigan Agr. Expt. Sta. Circular Bul. 166:3-10.

Vetanovetz, R. and R. Hulme. 1991. Tested your water alkalinity lately? Greenhouse Manager 9(10):48-50.

Vetanovetz, R.P. and J.F. Knauss. 1988. Water quality. Greenhouse Manager 6(12):64-72.

Warncke, D.D. 1986. Analyzing greenhouse growth media by the saturation extraction method. HortScience 21:223-225.

Warncke, D. and D. Krauskopf. 1983. Greenhouse media: Testing and nutrition guidelines. Michigan State Univ. Ext. Bul. E-1736.

Williams, B.J., J.C. Peterson, and J.D. Utzinger. 1988a. Effects of dolomitic lime and alkaline water in sphagnum peat-based container growing media. HortScience 23:168-169.

Williams, B.J., J.C. Peterson, and J.D. Utzinger. 1988b. Liming reactions in sphagnum peat-based growing media. J. Amer. Soc. Hort. Sci. 113:210-214.

Yeager, T.H. and J.E. Barrett. 1985. Phosphorus and sulphur leaching from an incubated superphosphate-amended container medium. HortScience 20:671-672.

Yelanich, M.V. 1995. Modeling the concentration of nitrogen in the root zone of container-grown chrysanthemums. PhD diss., Michigan State Univ., East Lansing.

Yelanich, M.V. and J.A. Biernbaum. 1993. Root-medium nutrient concentration and growth of poinsettia at three fertilizer concentrations and four leaching fractions. J. Amer. Soc. Hort. Sci. 118:771-776.

Young, R. and F.J. Johnson. 1982. Fertilizer products, p. 45-68. In: The fertilizer handbook. Fertilizer Inst., Washington, D.C. 